Portland State University

PDXScholar

7-28-1971

\title{
Communicative Abilities: an Analysis of the Interactions of Reticent and Non-reticent Task Groups
}

Myron W. Lustig

Portland State University

Follow this and additional works at: https://pdxscholar.library.pdx.edu/open_access_etds

Part of the Interpersonal and Small Group Communication Commons Let us know how access to this document benefits you.

\section{Recommended Citation}

Lustig, Myron W., "Communicative Abilities: an Analysis of the Interactions of Reticent and Non-reticent Task Groups" (1971). Dissertations and Theses. Paper 1590.

https://doi.org/10.15760/etd.1589

This Thesis is brought to you for free and open access. It has been accepted for inclusion in Dissertations and Theses by an authorized administrator of PDXScholar. Please contact us if we can make this document more accessible: pdxscholar@pdx.edu. 
AN ABSTEACY OF THE THESIS OF Myron $W$. Lustig for the Master of

Science in Speech presentec July 28, $197 \AA$.

Title: Commicative Abilities: An analysis of the Interactions of Keticent anä Non-Reticent Task Groups.

APROVED BY MEMERS OF THE THESTS COMITSEE:

A

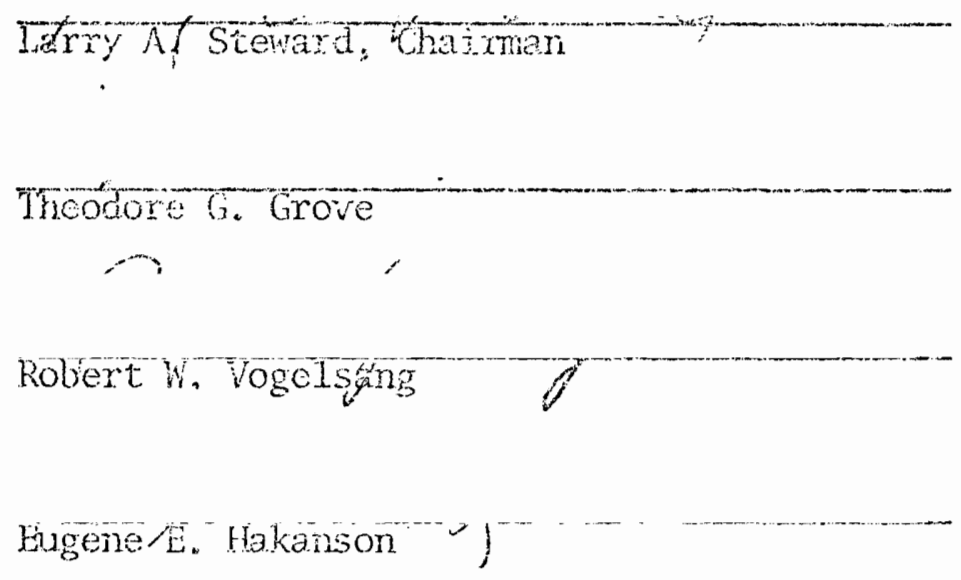

This study is focussed upon an investigation of observable interactive behaviors which night be cheracteristic of reticence. A reticent individual is defined as one for whom apprebension about participation in oral commication consistently outweighs the projection of gain fiom the situation.

previous research in the area of reticence has been focussed on an analysis of the reticent student's attitudes toward comnuication, relying primarijy upon subject self-reports via journals and the in-depth interview. This in turn has provided possible areas in which 
observable reticent benaviors might evidence themselves in face-to-face small grouj commications with other reticents and non-reticents. An answer to the following question was sought: In what ways and to what extent are the interactive profiles of task groups with reticent mombers similar to eech other in the anout and distribution of task and social-emotional acts, and to what extent are they different from the groups with no reticent nembers?

Twenty-four subjects, six reticent and eighteen mon-reticent, were selected from the population of students enrolied in Fundanentals of Speech at Portiand State University, Spring Term, 1971. Prior to the study, the reticent subjects were identified according to performance on a paper-and-pencil tost devigned to expose speech fears, and a preliminary interview.

Subjects were diviad into six four-person groups. Three of the groups consisted of two reticent and two non-reticent members, while the remaining three groups were composeci of four non-reticent subjects. Each group participated in a single fiftyminnte discussion. Data fron the grow intenactions were subjected to statisticai interpretation based upon the twelve categories established by Robert F. Bales in his Interaction Process Analysis system. The hypotheses tested, and the principal findings, are as follows: Hypothesis I: The groups with reticent members will have a significantly smiler total of all acts initiated than will the groups with no reticent members. 
This hypothesis failed to be confimed. No significant differences were revealed in the total number of acts initiated. Because of this result, a test was made for differences in the anount of talking initiated by reticent and non-reticent subjects. No sigifificant differences were found. It was therefore ascertained that no differences exist in the number of acts initiated by reticent and nonreticent subjects, nor are their differences in the total number of acts initiated by the groups in which they interact. Hypothesis II: Within the groups with reticent members, the reticents wili address significantly nore acts to non-reticents than to other reticicents.

This hypothesis was also unsubstantiated. The reticent person initiates the same number of acts to other reticents as to non-reticents. Hypothesis III: In a comparison of groups with reticent nembers and groups with no reticent reticent members, there will be no significant differences in the acts scored in the variou; categories of the interaction analysis.

Significant differences were found in the distribution of total acts and acts scored in the "task and social-emotional" areas. A further breakiown of the task categories revealed differences in the area "guestions and attempted answers." The distribution of acts in the "positive and negative" categories of the socialmemotiond area revealed no significant dicferences between the two types of groups. In short, although the interaction analysis successfully discriminated between the groups with reticent members and groups with 
no reficent members, the djfferences are subtle enough to make it impossible to ascertain which students are truly "nomal" arid which are merely masking the more serjous reticent symptoms. It is therefore concluded that, precisely because the reticent student is unrecognjzable from his peers, pedagogies applicable to the reticent student should be implemented in the traditional speech classroom. Further research in the area of reticence is needed in the following folr areas:

1. Delineation of similarities and differences between those reticents chasacterized by their silence and those characterized by their verbosity.

2. Determination of the incidence and nature of reticent problems in the elementary and secondary school populations.

3. Development of pedagogies applicable to the reticent popu1ation.

4. Levelopment of standardized measuring instruments for :reticence" and "attitudes toward communication." 
COMMUNICATIVE ABILITIES: AN ANALYSIS OF THE INTERACTIONS OF RETICENT AND NON-RETICENT TASK GROUPS

by

MYRON W. LUSTIG

A thesis submitted in partial fulfillment of the requirements for the degree of

MASTER OF SCIENCE

in

SPEECH

Portland State University

1971 
TO THE OFFICE OF GRADUATE STUDIES:

The members of the Committee approve the thesis of Myron W. Lustig procantad Tin1 201071

Karry A. Steward, Chd1rman

Theodore G. Grove

Robèrt W. Vogelsang

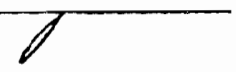

Eugene $\not \subset$. Hakanson

) =

APPROVED:

PobertW. Uogelangeng

Robert W. Vogelsand, Head, Department of Speech

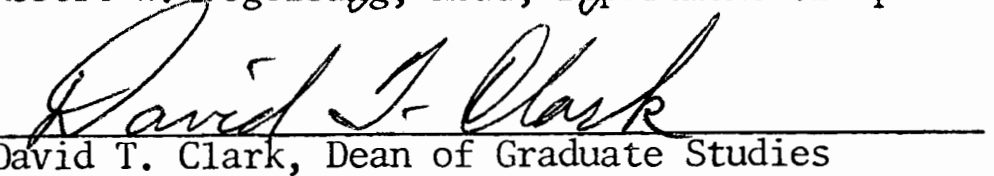

July 30,1971 


\section{ACKNOWJDCWENTS}

It seeins only appropuiate to acknowiedge those who contributed so willingly to whatever merit this thesis might have. 1 am especially indebted to my chaiman, Br. Larry A. Steward, who helped me to clarify tine concept of reticence, anri to ir. Theodore G. Grove, whose contribution of time and assistance helped to present the theory aid practice of experimental methodology and design.

Thanks are also due to the Comnittee for Research on Teaching in granting finantial assistance. Messus. Stopren G. Dick, Glenn l. Ingram, Gary Robinson and Robert Rosenkranz contributed their time and expertice as interaction andiysis raters. Ir. Stephen Kosokoff, Mrs. Carolyn Young and Mr. Robert C. Harrey assisted in providing the subjects for the study. And the subjects themselves, who must remain unnamed, contributed their time and trust in the completion of this thẹsis.

Lastiy, I wish to express niy gratitude to my wife Nicole. Her perseverance, patience and devotion dirring the long hours in which this thesis was being written and assembiei contributed inneasurabiy. To her, and the others, I am indeed grateful. 
TABLE OF CONTENTS

PAGE

ACKNOWLEDGMENTS ...................... . . . . . . . . . . . . . . .

LIST OF TABLES ...................... . . . . . vi

LIST OF FIGURES . . . . . . . . . . . . . . . . . v vii

CHAPTER

I INTRODUCTION . . . . . . . . . . . . . . 1

II REVIEW OF THE LITERATURE . . . . . . . . . . . . 4

II I PROBLEM AND PROCEDURES . . . . . . . . . . . . . 32

Genesis of the Problem ............

Rationale for the Approach . . . . . . . . 33

Statement of the Problem . . . . . . . . . 34

Hypotheses to be Tested ........... 34

Definition of Terms ........... 37

Assumptions Concerning Interaction Analysis . . 38

Interaction Sequences .......... . . 40

Population and Procedures ..........

Rationale for the Procedure .......... 45

Rationale for the Task . . . . . . . . . 46

Limitations .............. . . . . . 47

IV RESULTS . . . . . . . . . . . . . . 51

V SUMMARY AND CONCLUSIONS .............. 61

Sumnary of the Results ........... 61 
CHAPTER

PAGE

Conclusions .... . . . . . . . . . .

Suggestions for Further Research . . . . . .

REFERENCES

APPENDICES . . . . . . . . . . . . . . . . . .

A Definitions of the Interaction Categories . . . . :

B NASA Group Consensus Problem . . . . . . . . .

C Grievances of Black Citizens Consensus Problem . . . . 


\section{LIST OF TABLES}

TABLE

PAGE

I Summary of Seven Wilcoxon Matched-Pairs Signed-Ranks

Tests for Effects on Group Interactive Profile . .

II $t$-Test for Total Acts Initiated . . . . . . . .

III Raw Scores for Number of Acts Reticent Subjects

Addressed to Other Reticents and Non-Reticents . . .

IV Raw Scores for Amount of Talking Initiated by

Reticent and Non-Reticent Individuals . . . . .

$\mathrm{V} t$-Test Results for Amount of Talking Initiated by

Reticent and Non-Reticent Subjects . . . . . .

VI Raw Scores for Reticent and Non-Reticent Groups

Across 12 Categories of Bales' I.P.A. . . . . .

VII Chi-Square Test for Differences in Positive and

Negative Social-Emotional Acts .........

VIII Chi-Square Test for Differences in Positive and

Negative Social-Emotional Acts . . . . . .

IX Chi-Square Test for Differences in "Questions" and "Attempted Answers" ............. 
$+$

\section{LIST OF FIGURES}

FIGURE

PAGE

1 Categories for Robert F. Bales' Interaction Process

Analysis System ............. 
CHAPTER I

INTRODUCTION

For many years, discerning speech teachers had observed that a certain small proportion of students in introductory classes did not seem to benefit from traditional pedagogical procedures. I Indeed many of these students seemed to get worse! Until recently, however, no systematic attempt had been made to understand the reasons for this occurrence.

Recognition of a common ground between psychology and speechconmunications led to a search for possible relationships between personality patterns and disorders of speech and communications. The existence of such relationships are now widely acknowledged (Cf. Review of the Literature). Speech disorders and personality disorders are now consiciered to be related maifunctions. This attitude is implicit in such definitions as: "A speech disorder is a disorder of: the person as well as a disorder in the reception and transmission of spoken language." 2 The implications of these findings serve to emphasize the nature of the responsibility assumed by the speech teacher in attempting to deal with speech problems encountered in the normal classroom.

In 1964, Frances Laura Muir began a study of this heretofore unexplainable occurrence. She found that the symptoms usually associated with stagefright and stuttering could be viewed as existing 
on a continum of comminicative behaviors. She therefore subsuned under the term "reticenre" a class of symptoms which included withdrawal, unwillingness to assume communjcative responsibility, and general anxiety. The common referent in all these behaviors, she observed, was the owerwhelming need on the part of this group of students to adopt behaviors which would allow then to withdraw or avoid the crmunicative situation.

In an attenpt to provide diagnostic measures of reticence, subsequent investigators have focussed on an analysis of the reticent's commuicative abilities, relying primarily on journal reforts and the in-deptl interview to collect the necessary data. This in turn has provided possible areas in which behavjors characteristic of the reticent personality may evidence themselves under controlled laboratory conditions.

It is the purpose of the present study, therefore, to investigate the observable interactive behaviors which might be characteristic of reticerice, hopeíully leading to an observational means of discriminating between the reticent and the non-reticent individual. Such a study would be an important contribution to the further understanding of the communicative abilities of the reticent population. 
Notes

1. Gerald M. Phillips, "Reticence: Pathology of the Normal Speaker," Speech Monographs, 35 (1968), 39-49.

2. Lee Edward Travis (ed.), Handbook of Speech Pathology (New York: Appleton-Century-Crofts, Inc., 1957), p. 965. Cited in Frances Laura Muir, Case Studies of Selected Examples of Reticence and Fluency (Unpublished Master's Thesis, Washington State University: Pullnan, Washington, 1964), p. 2. 
REVIEW OF THE LITERATURE

This chapter will review the 1iterature pertinent to this study. The works produced by Nuir, ${ }^{1}$ Phillips, ${ }^{2}$ Phillips and Butt, ${ }^{3}$ Steward, ${ }^{4}$ Hopf ${ }^{5}$ Ickes, 6 and Bush and Bittner ${ }^{7}$ together provide a comprehensive review of the literature relevart to this thesis.

The germinal work in the area known as "reticence" was done in an unpublished thesis by Fancis L. Muir: Case Studies of Selected Examples of Reticence and Flueicy. In her 1964 study, Muir used the term "reticence" to designate a particular kind of communicative disorder. She concluded that it was possible to subsume under "reticence" a class of symptoms usuaily referred to as "stagefright," and placed stagefright on a continum of maladaptive specch behaviors which included such symptoms as withdrawal, unwillingness to assume communicative responsibility, and general anxiety.

The term "reticence" was chosen by Mij.r on the basis of a dictionary definition: "Avoidance of social, verbal interaction. Unwillingness to communicate uniess prodded; disposed to be silent; not inclined to speak freely; reserved." 8 Muir suggested that reticent speech, so described, might be construed as defective speech as it conforms to Van Riper's definition, "Speech is defective when it deviates so far from the speech of other people that it calls attention to itself, interferes with communication, or causes the possessor to be 
maladjusted."9 "In short," says Muir, "when reticence becomes a problem for the reticent person it could be considered defective speech."10 Mair produced her data by interviewing six reticent and three non-reticent subjects salecied from over 400 students enrolled in the basic speech course at irashington State University. They were selected on the basis of instructur's recomenciations and a preliminary interview. The interviews were taped, converted to manuscript and subjected to content analysis.

One of Muir's objectives in her investigation was to "isolate behavior which might be characteristic of reticence."11 In expiicating the patterns of reticent speech, two kinds of data were collected: the subject's evaluation of his own conversational abilities, and the interviewer's evaluation of the subject's voice and mannerisms. 12 Both of these evaluations have a direct bearing on the present investigation.

The subject's evaluation of his own conversational abilities was acceptable for the purposes of Muir's study since a factor of reticence was presumed to be the individual's assessment of his own communicative performance. To bulwark this argument, she quotes MacDonald who says that there exists a "high degree of agreement between self-ratings and associate's rating of conversational ability suggesting that most college students can accurately evaluate their conversational ability."13 However, while it may be true that most college students can accurately evaluate their own conversational abilities, this does not imply that reticent students are capable of this accomplishment. Indeed, there may even be high degree of 
correlation between reticence and the irability to evaluate oneself accurately in converstion situations, since this inability may be a factor in the reticent behavior being investigated! Both Muir's assumption and the above analysis seem equally plausibje.

The interviewer's evaluation of the subject's voice and mannerisms could come under similar scrutiny. Muir reports that "a low voice, lacking in inflection and accompanied by hesitant speech, was most frequently observed. Overall bodily responses appeared to indicate a degree of lethargy."14

In making this assessment, four factors were taken into consideration: 15

1. The subject's nonverbal responses including posture, gestures, physical mannerisms, and reaction.

2. The freedom with which the subject volunteered information, e.g., the number of probe questions necessary, the length of response, the inclusion of information not requested.

3. The subject's evaluation of and reaction to both subjectiveiy and objectively oriented material.

4. The subject's voice quality and inflection pattern.

Here again, it is reasonable to assume that the interview situation is not characteristic of the settings in which the reticent subjects normally function. The hesitancies in the voice and mannerisms may be related to a combination of factors including the uniqueness of the interview situation as well as the discussion of his failure in such sensitive areas as present and past social stress situations. Another of Muir's objectives in her investigation of reticence was to "analyze data in an attempt to relate factors in the developmental and social background cf the reticent individual to his present 
communicative behavior."16 She therefore formulated categories through which she could content analyze the material obtained in the interviews.

The four major categories are listed below along with the subcategories for each: 17

I. Conversational Patterns of the Individual
A. Voice and Mannerisms
B. Content and Manner of Comunication
C. Most Threat Persons
D. Least Threat Persons
E. Most Threat Situations
F. Least Threat Situations
G. Emotional Reactions to Speech Situations

II. Environmental Background

A. Home Environment

1. Socio-Economic Status of Family

2. Parent's Educational Accomplishment

3. Parent's Religious Affiliation

4. Family Relationships

5. Conversational Patterns

B. Community

1. Type of Community

2. Stabiiity of Residence of Fanily

3. Family Relationship to Community

III. Social Adjustment

A. School 
B. Present Socjal. Adjustment

IV. Vallies and Goals
A. Religious Values
B. Political Values
C. Moral Values
D. Social Values
E. Goal Aspirations

Categories I and III in the Muir study revealed information most pertinent to later investigations, including the present one. She found, among other things, that:

A. Reticent subjects generaily "reported being extremely conscious of the inanrier in which they phrased their ideas. They attacined great importance to the words used."13 In addition, a11 of the reticent subjects felt that, at least in some instances, "the content of their communication would not interest others."19 This observation is similar to findings in Steward's study conceming the high degree of "conscious awareness of the speech act."20

B. "Least threat persons were those who demanded a minimun of communicative responsibility, e.g., children, tradesmen, accepting family members" while "most threat persons most frequently reported were authority figures and persons who might threaten self-image or ideas (professors, opinionated persons, different faith persons). 21 The above observation is in general accord with the findings of Steward ${ }^{22}$ and Phillips. 23 For the present investigation, it is assumed that the reticent subjects' most threat and least threat persons were absent from the situations being investigated. 
C. Most threat situations reported were communicative and/or social stress situations."24 Further, Muir reports that "communicative responsibility caused anxiety and tension." 25 This has a direct bearing on the present investigation because of the implication that groups with reticent members should have high instances of showing tension and withirawal and possibly tension release.

D. A11 of the reticent subjects "experienced varying degrees of anyiety, self-consciousness, tension, and self-reproach in unpleasant conversationai situations" and "all expressed a desire to avoid such situations" 26 Again, this sipports the notion that high levels of shuing tension and withdrawal should be found.

E. Reticent subjects "evaluated their conversational ability and themselves negativejy, at least in the context of certain commuricative situations." 27 This finding, as vell as a similar one by Steward, 28 clearly incijcates that negative self-image is a central consideration in the reticent speech personality.

Muir's focus on "environmental background" and "və.lues and goals" exposed certain other etiological and nosological factors of reticence. While careful not to attribute a "cause and effect" relationship between these sociological factors and the incidence of reticence, Muir's data revealed what might appear to be a marked disadvantage in the developmentai backgrounds of the reticent group. She found, for the most part, that reticent subjects reported family relationships to be "cool, strained, or actively hostile"; 29 in addition, conversation within the family was "frequently carried on at the 'utility' leve1, often with overtones of unpleasantness."30 Values 
(especially religious values) of the reticent group were not inculcated, and tended to be "vaguely defined," negatively stated," or "loosely held." 31 Muir also reports that one or more of the following factors was operative in the community environment: "upward mobility (competitive); charge of residence, fanily were 'outsiders'; minimum parental interest was showi in church or conmunity affairs."32 Finally, social activity was low in that "the subjects tended not to identify strongly with any group" and they "participated less in school and community groups." 33

Muir concludes her thesis by operationally defining reticence as "a disordered comminication pattern manifested in abnomal silence or abnormal quantity of speech."34. Although this definition inciudes both the overly silent and the highly verbal, she cautions that not all quiet persons nor all verbose persons should sumnarily be classified as reticent.

The influence of Muir's work on all future investigations is readily apparent, both in her description of the problem of reticence and in the implications for future theoretical and empirical research which others have explored. In summarizing her work, Steward writes the following: 35

Finding subjects, then, whose communicative behavior seemed to be a problem to themselves and others, Muir could, with good authority, relegate these problems to the area of "speech defects," even though the problens manifested could not be classified according to known patiologies. By appropriating a label, Muir focused attention on a condition, the existence of which had been indicateł, bui largely neglected by previous researchers.

The first published appeararce of the term "reticence" to denote an "abnomality of speech behavior" requjrirg special means of 
diagnosis and treatment was in an article "The Problem of Reticence" by G. M. Phillips. In his 1965 article, Phillips emphasizes the relationship between speech and personality, utilizing the existence of the reticent student in traditional speech classes as the basis for launching a vigorous attack on current assumptions and practices in the teaching of speech.

In the first portion of his article, Phillips emphasizes that: (1) there exists a definite relationship between speech behavior and personality; (2) speech behavior is therefore neither separable from personality nor trainable apart from the personality as a whole; and (3) reticence could be constmed as existing on a continum with stuttering and stagefright, all of which represent "ways in which persons whose personality needs impel them to withdraw or avoid the communcation meet this need in their communication behavior."36 He then places reticence into a broader speculative framework by suggesting that the term "reticence" should perhaps be used as a nosological category for a wide range of comnunicative disorders. He states:

A human being who seeks to mask his emotions or hide his values and/or suffers threat from the existence of potential responses to his communication may elect to withdraw through stuttering, through manifest stagefright, through monosyllabic responses, chrough maintenance of a phatic level of communication, through compulsive interaction, etc. Regardless of the specific method elected, it serves as an explanation to the individual for failura to cope with the role-demands of society. Reticence may thus mean more than jow quantity in verbal output, but rather denote a nosologic category for any comnunicative discrder which results in reducing the effectiveness of the individual in the normative verbal intercourse demanded by his culture. 37

In the second part of his article, Phillips discusses the clinical implications of his premises for the teacher of speech. In 
describing the potentially damaging results which may result if the above premises are ignored, he points to the comnon practice of classroom criticism of speech performances.

When the threatened speaker exposes his personality and his values, he expects to be reacted to as 'person' rather than 'performer.' But standard criticisms are performance oriented. One response is to withdraw into duliness, to play the game as best he can and preserve a little selfesteem. The threat of the criticism, however, will affect his personality and his communication ability for a long time to come. 38

The threat is even more severe for the reticent student. Feeling inadequate to the speaking occasion, having already admitted failure, criticism for the reticent speaker oniy tends to perpetuate his already negative jmage. Thus the speaking situation is an invitation of exposure to unmanageable threat, and if the challenge is accepted, only results in turther penaliies. fgain, according to Phisilips:

The reticent (substitute " $\mathrm{C}$ ") speaker is penalized by both criticism and a poor grade. This is a shock to a vulnerable personality that may have exposed itse1f, Negative reinforcemeric results, particularly wher peers are permitted to join in the criticism. Their insensitvity to threat cues often leacis them to overcriticize, particulary projections of intrinsic personality mechanisms, heightening the threat to the phenomenal self of the speaker that was exposed, osterisibly to meet the new rules of the speech class game ... For the reticent speaker, peer criticism only reinforces negative self image and a further penalty is exacted for a failure he has already admitted and expected would not figure in the game. 39

Phillips therefore asserts that the speech teacher must learn to adapt clinical methodologies for the classroom. Recognizing that the speech teacher is not a psychoanalyst, he nevertheless feels that "he cannot be permitted to be an authoritarian director of perform-" ance. "40 Even though a student may, under pressure of a required 
course in speech and the necessity for achieving good grades, make an honest attempt to master the classrocm situation, the assumption that carry-over will occur in situations outside the classroom is "not fully tenable." Rather, Phillips feels that such forced adaptation jmposed by temporary authoritarian threat may interfere even more with future performances. For these reasons, it behooves the teaciner of speech to know something of the personality dimensions of his students and to adjust his pedagogy accordingly.

In conclusion, Phillips states that there is no question that a clinical approach to the teaching of speech is necessary. The widespread incidence of reticent symptoms in the typical population of speech students is sufficient to warrent a "broad re-evaluation of pedagogical assumptions and methols"41 in the speech classroom.

In a follow-up article, "Reticence Revisited," Phillips and Butt discuss their attempts to design and implement classroon methodologies which are applicable to the reticent student. Declaring at the outset: that they are "so involved emotionally with the clinical treatment of verbal reticence that [they] wish to throw caution to the winds, "42 an attack is launched on some traditional assiamptions prevalent in the required speech course for beginning students:

Our tradjtional speech pedagogy takes for granted that students can be trained to overcome their "handicap" by simple exposure to experiences and criticism. A pattern evolves; students perform and are criticized. They will improve as a result of the criticism. They will automatically integrate complex cognitive material from text, lecture and criticisms into their performance and their attitude toward speaking. If they do not improve, it implies a willful rejection of "revealed wisdom" and punishment is justified. Punishment is administered in the form of a poor grade, and reinforced 
by negative criticisn from instructor and peers. The supposition is that this combination of factors will produce "good speakers." 43

The authors then contend that the typical speech classroom can be viewed as a formal "game," the object of which is to earn an "A" or "B." Nowhere in the "game" is a provision made for develcping a healthy relationship between the teacher and his students, and little or no attempt is made to measure "gain" in comlunication ability in the student's life experience. Phillips and Butt therefore state that "in the context of a required course, considerably more attention must be paid to individual needs and far less attention to the rigorous demands of the discipline of public speaking. "44

The next portion of their article discusses a pilot program which was begun at The Pennsylvania State University in order to assist those students identified as having real communication problems. One-hundredfifty-four students in four classes participated in the program; all classes were conducted in a clinical manner. Enphasis was placed on individual activity, and individual contact between teacher and student was stressed. It was made clear to the students that no part of their grade depended on their speech performances. Grading was confined to nastery of cognitive material.

A11 students were required to keep a daily diary of their reactions to the course and to their conmunication experiences outside of the classroom. Information from the diaries was used both by the student to assess his progress and by the instructor to gain feedback about his effectiveness. In addition to this classroom effort, psychclogists from the Counseiling Center and speech therapists were 
used as supporting personnel.

Phillips and Butt report that five major premises guided the teaching of the reticence classes: ${ }^{45}$

1. The function of the teacher is to paricipate with the students, not to control or coerce him.

2. The situation, as seen by the student, determines the extent to which progress toward a future goal is possible.

3. The student must play an active role in determining what is to be leamed, particularly if what is to be learned is behaviora] or affective.

4. The single most important aspect in the learning process is the interaction between teacher and student.

5. Regardless of the length of time the relationship existed, some progress could be inlade toward facilitating adjustment to a commuricating self by the student.

The authors report that response to instruction in the reticence section generally seened gool, and they provide some typical cases as doccmentation. Most students seemed to improve a little; virtually all reported that the course had been a great deal of help. This result is especialiy noteworthy, since nearly one-fourth of the students had started the course in previous terms and had dropped it. While Phillips and Butt realize that few reticent students will become proficient at puiblic address, they conclude that most are capable of discovering a great deal about thejr abilities as commicators, hopefuliy leading to an accurate and optimistic assessment of what may be expected in future comminication experiences.

The next major investigation of the reticent personality was in a 1968 dissertation by L. A. Steward. In his study, Steward 
delineated several major differences in the backgrounds, perceptions, and attitudes of reticent and non-reticent individuals, focussing on the various concepts as perceived by the subjects in his study.

In defining reticence, Steward cites Hopf who says the reticent individual is "one for whom the anxiety which accompanies thie comnunicative act consistently outweighs the projected reward or precludes the consideration of a successfui performance."46 Thus the reticent individual is considered to be a person whe "consistently exhibits anxiety in cormrunicative sj.tuations becalise of the way in which he perceives and evaluates his actual or projected performance, which in turn results in the selection of inappropriate behavior."47

Data were produced by interviewing eight reticent and eight non-reticent subjects selected from the population of students enrolled in the beginning speech course required of all undergraduates at The Pennsylvania State University. They were selected on the basis of performance on a paper and pencil test for "Speech Fears" and a preliminary interview. As in Mir's study, the interviews were taped, converted to manuscript and subjected to content analysis.

The nine categories used in the content analysis of the interviews were: (1) Most Threat Persons, (2) Least Threat Persons, (3) Most Threat Situations, (4) Least Threat Situations, (5) Communicative Patterns: Genera1, (6) Communicative Patterns: Specific, (7) Cohesiveness, (8) Extra-Familial Relationships, and (9) Attitude Toward Cormunication. Each category of the content analysis "successfully discriminated between the two groups with very little overlap of individuals." 48 
While many differences nere ofscrved, several dominant themes emerged as the most characteristic of reticence as well as the most promising for the future development of procedures for identifying the reticent personality. They were:

A. "A meaningful difference appeared in the number of identifications made of individuals or types of individuals who could be regarded as threatening ... Also, the general level of threat appeared much lower for the non-R's."49 This observaton, that the reticent subjects are able to identify a greater number of specific "Most Threat Persons," indicates that "they are threatened by more people and more severely than the non-reticent subjects."50 Responses to "Most Threat Persons" by reticent subjects "are usualiy naladaptive, are typically perceived as gaining negative resuits and are followed by self negation." 51 Thus the most common responses are avoidance, withdrawal, and deference.

B. The reticent subjects reported "minimal or no comnunicative contact beyond the utility level with adults outside of the immediate family."152 Conversely, all of the non-reticents reported "favorable and valued relationships with adults outside of the family circle." 53 Fjve of the reticent subjects identified one or more of either "Adults in General," "Authority Figures," or "Teachers" as the "Most Threat Person" outside of the family. None of these same subjects could recall any teacher or adult outside of the family with whom they had shared a meaningful and favorable communicative relationship. This finding "points to the possibility that the absence of such relationships might be an importanit factor in the etiology of reticence."54 
C. Within the imrericite family, all reticent subjects indicated one or more members as "Most Threat Persons." In addition, the reticent subjects, as a group, "perceived communication with parents as significantly less rewarding" 55 than the non-reticent subjects. It was also discovered that when a Most Threat Person (MTP) exists within the family, "people outside the fanily who denonstrate similar characteristics are simply regarded as MTP's."56 These observations indicate that the perception of a threatening relationship within the family may be a significant factor in the development of the reticent personality. As Steward states, "The presence of a threatening personality in the home precludes effective avoidance and provides a coristant reminder of personal inadequacies of the subject as perceived in that relatjonship ... The constant reminder of inadequacy in the home and the attendant perception of threat could be generalized to others outside the family when similar characteristics are recognized." 57

D. Generally, reticent subjects reported experiencing "confict between values of home and peer groups." 58 The result, in many cases, was that "friends were not accepted and/or made to feel comfortable in the home." 59 The reverse was true of the nonreticent subjects. In explaining this finding, Steward theorizes that "acceptability of friends to the family as well as compatibility in norms and values as perceived by the individual are somehow associated with the development of the effective speech personality."60

E. "Wi.ther a favorable communicative atrosphere at home, or significant relationships with adults outside of the family, or both, 
is essential to but does not guarantee the development of an effective speech personality."61 Thus, the wider the range of successful communicative contact, the greater are the chances of developing "a similarly wide range in repertoires of effective speech behaviors as we11 as confidence in their employment." 62

of particular interest to this study is Steward's statement that: :

Observation of behavioral characteristics offers little for purposes of discrimination between the reticent and the non-reticent individual. That is, manifestations of speech fear and other maladaptive behaviors may be quite normal responses due to unfamiliarity and lack of knowledge concerning appropriate behavior in the situation. 63

A1though the above statement was not based on a controiled laboratory investigation of behavioral characteristics, it does imply that no differences should be found in the social-emotional areas of the interaction analysis.

At a later point in his study, Steward explains that:

This uncertainty concerning the meaning of behavioral characteristics is due to the prodigious capacity of human beings to hide, substitute, mask or otherwide deny from the observer evidences of symptoms perceived by the individual to be socially unacceptable. Individuals behave in such a way as to preserve the best possible selfimage and to elicit the most acceptable responses from others. Reticence may then be manifest in any behavior that the subject is capable of exhibiting and which is perceived by him as more desirable than a display of his true feelings regarding self and communication. So it is that verbosity, withdraval, avoidance, hostiiity and other manifestations will be exhibited to 84 thers rather than attempts at genuine communication. 64

He therefore emphasizes that the concept of reticence "does not describe behavioral dimensions, but rather an attitude toward the self with regard to the communicative act."65 
The proclivity on the part of the reticent student to mask undesirable symptoms with various coping behaviors and thus avoid confronting his own inadequate communicative behavior is well documented in Steward's data; he therefore rightly asserts that this tendency must be taken into consideration in the design of instruments to identify the reticent, as well as in the design of a pedagogy in general. Consequently, Steward feels that measuring instruments such as the Likert Scales or the Q-sort should be designed to illuminate the various attitudes and behaviors characteristic of the reticent personality.

His concluding implications for pedagogy are based on the assumptions that (a) the reticent studert is unable to consider himself as a successful comminicator in circumstances that are meaningful to him; (b) he is largely unabie to assess his present and/or potential skills realistically; and (c) his attitude toward the communicative act militates against a purposeful pursuit of skills and prevents his recognition of sucin skills when and if they occur. 66 Thus three major objectives for an effective peckagogy are proposed. A successful course in Speech would help the reticent student:

1. T'o alter perceptions of self and others in relevant communicative acts.

2. To appreciate the principles of the human communication process so as to be able to assess their own strengths and weaknesses realistically.

3. To adopt effective speech behaviors which are recognized as such by the speaker as we 11 as other participants in the communicative act. 67 
It is further suggested that classroom procedures to carry out these objectives would maximize opportunities for favorabie communicative contact among stuaients and jnstructors in a relatively threatfree environment.

Published concurrently with Steward's dissertation was an article by G. M. Phillips entitled "Reticence: Pathology of the Normal Speaker." Phillips raises the problem of understanding persons with communicative problems which "cannot be clearly ficted into accepted. diagnostic categories but which, nevertheless, dismpt the socjal adjustment of the speaker and reduce his effectiveness as a conmunicator."168 Such a person!

shows no distortions in articulation, nor does he rereal the hypertonia associated with stuttering. He is usually quiet and tends to avoid interaction. He is reluctant to discuss iceas and problems with others and seens inordinately intimidated by superordinates. He rarely asks questions, does not socialize weli, and physical upsets are often associated with his attempts to communicate ... He does not anticipate success in comnunicative transactions involving speech.69

Labeled as "reticent," Phillips defines such an individual as "a person for whom anxiety about participation in oral comminication outweighs his projection of gain from the situation."70

In order to isolate specific behaviors associated with reticence, Phillips made a study of diary reports from 198 college-age persons who were characterized as "severely inadequate oral comminicators."71 Data from this group were compared to similar data from 1100 students identified as non-reticent. Based on this comparison, the following features were identified as characteristic of the reticent population: ${ }^{72}$ 
1. They reported shakiness which interfered with thein attempts to commmicate during classroom recitations and public performances.

2. They reported that during attenpts to speak they were conscious of physical symptoms, "butterflies in the stomach," loud or rapid heartbeat, hesdache, throbbing temples, nausea, excessive perspiration, and inability to see the audience ... Reticent subjects aiso reported that they felt no sense of relief or accomplishment at the completion of a communication.

3. Virtually all reticent subjects reported that, on occasion, they found it necessary to break off communication with someone abruptly because of their fears and apprehensions.

4. Reticents expressed inability to communicate with "important" people like teachers or counselors... They aiso reported an inability to talk about personal problems with others.

5. Others, such as parents or teachers, had called communicaitive inadequacies to the attention of reticonts, or, at least, reticents remembered more occasions wiven this had happened than normais remembered.

6. Most reticents had an image of themselves as excessively quiet and saw themselves consistently on the iringes of social gatherings.

7. Reticents felt compelied to be unnaturally apologetic when their ideas were challenged and they interpreted questions about content of communication as personal criticisms.

8. Reticents preferred to communicate in writing where possible and most had achieved a fairly high level of skill at writing. Virtually all mentioned problems they had had with oral performances in public school and remenbered frequently receiving poor grades on such public performances.

9. Most reticents expressed singular inability to talk with their parents.

Based on these characteristics, Phillips regards a reticent person as one who habituates certain communicative behaviors in orảer to avoid certain anxiety-producing situations, even though the be- 
havior no longer aids in the avoidance or reduction of the anxiety. Thus

... any normal speaker could occasionally be defective in a given situation. But as the number of situations with which he cannot cope increases, the general involvement of his personality would be expected to become greater. If a comiunicator $\ldots$ constantly fails, his at tude towara comminication will become increasingly negative. 7

Therefore, the reticent "takes refuge from the demands with which he cannot cope by beconing more reticent. 174

Extended interviews with reticent college students indicate to Phillips that, for them, reticence is a response pattern that extends across all or nearly all communicative situations and that nontheless severely hampers their oral communication behavior.

The implications of these findings seem clear. If the reticent student exists as a person separate from the "normal" speaker, it is implied that pedagogy geared to improvement of those more skilled in oral communications are likely to threaten and intimidate him - especially where formal, public speech is required. Yet, paradoxically, if reticence can be considered to be a pathology of the "normal" speaker, whatever treatment is applied must be done in a typical classroom, but in a clinical fashion.

Phillips concludes by emphasizing the need for refining information essential to the identification of the reticent person. We don't know, for example, the incidence and severity of reticent communicative patterns below the college level. Theorizing that reticence may be more prevalent in the lower grades, he reasons that their maladaptive communicative pattern may have iripeded the 
intellectual. growth of the futire college student. The answers to questions such as these, Phillips asserts, deserye prompt testing. Two recent researchers, Hopf ${ }^{75}$ and Ickes, ${ }^{76}$ have independently reported tiveir attempts to reduce the anxiety levels of reticent subjects. Hopf, working within the context of the normal speech classroom, suggests using various exercises in Oral Interpretation to further the reticent student's ability in other areas of oral conmunjcation. Recognizing that a major concern of the reticent student involves "self-esteem," he feels that

Oral interpretation may be considered as a functional device for coping with 'self-esteem' and the subsequent problems of self-image since it allows the student - for the time being - to operate on a "not me" basis. That is, the material and the way in which written content is organized may not necessarily be perceived by the reticent reader as a function of 'self.' 77

Ickes, ${ }^{78}$ on the other hand, in presenting a classical conditioning model for reticence, utilizes a clinical setting for treatment. Viewing reticence as "undesirable learned behavior,"79 he attermts an explanation of the reticent speaker within a model of learned neurotic behavior. Thus Ickes suggests the employment of behavioral modification techniques (in this case systematic desensitization therapy) to alleviate the problem.

Ickes conception of what constitutes "reticence" seems to be vastly different from all previous investigators. For example, he states that "reticence is directly attributed to neurotic anxiety that appears when the conditioned subject is confronted with a group speaking situation." 80 Ickes seems to be saying that neurotic anxiety is the "cause" of reticence, while previous investigators 
have considered it to be only a symptom. Further, Ickes states that "what the therapy was designed to do was to eliminate the neurotic anxiety that the subject was experiencing." 81 Aside from the obvious difference, that all previous investigators state the classroom, and not the clinic, is the proper setting for any "therapy" which might be applied to reticent subjects, the major difference seems to be that Ickes equates "revrotic anxiety" with reticence and then proceeds to discuss anxiety and reticence as if they were synonymous. The problen is compounded when it is realized that many of the overt symptoms of reticence and neurotic anxiety, such as "butterflies in the stomach," may be the same, al though there seems to be a definite distinction between the two. Reticence is considered by Steward ${ }^{\$ 2}$ to be be an attitude toward commication; neurotic anxiety may be viewed as merely a 1abel for a set of behaviors. Thus it may be argued that Ickes, in using a classical conditioning moriel of neurosis, is working towards the alleviation of something other than reticence. That reticent attitudes manifesting thenselves within the individual may also be improved cloes not denigrate this argument. If, as previous investigators have implied, reticence is an attitude toward the self with regard to the communicative situation, than any change in the organism's behavior will cause corresponding changes in his attitudes toward himself. It is this dimension, the negative attitude of the speaker towards himself as a person with "butterflies in the stomach," that forms the basis of models of reticence. Thus, while it is agreed that the form of therapy selected may help to alleviate reticence, Ickes' rationale for its enployment is in sharp contrast with all 
previcus researchers.

The finaj study to ba reviewed, by Bush and Bittner, 82 does not have a direct bearing on the present irvestigation but does indicate that the term "reticence" may be used quite differently from the manner reported by the investigators in this Review of the Literature. Bush and Bittner discuss the effect of the video-tape recorder on levels of anxiety, exhibitionish, and reticence, cortsidering reticence to be "avojdarce of any interaction." 83 A comparison of responses between subjects speaking with the video-tape recorder present and visibie and those withcut the presence of the video-tape machine indicate that higher levels of all three variables did not occur. They therefore conclude that the presence of the video-tape recorder in a classrom speaking situation does not create any regative aspects of speaker response.

The results of this stidy, however, do not have a direct bearing on the present investigation singly because the tern "reticence" as used by Bush and Bittner differs considerabiy from the usage of previous investigators. Reticonce as used by Muir, 84 Steward, ${ }^{85}$ and Phillips 86 refers to a type of person differing from the "nomal" person by virtue of his attitude toward himself as an inadequate conmunicator. The sane term as used by Bush and Bittner seems to refer to a trait in nomal speakers which is capable of varying with the introduction of paxticular externai variables (in this case the video-tape recorder). Although Bush and Bittner indicate that "reticence" is dependont upon one's self-concopt as a 
comminator, the disparity in the ways the term is used points to the need for more clearly defined operational definitions. 
Notes

1. Prances Laura Mir, Case Studies of Selected Examples of Reticence and Fuency (Unrublished Master's Thesis, Washington State University: Fulman, Washington, 1964).

2. Gerald M. Phillips, "The Problem of reticence," The Pemsyluaria Speech Amua1, XXII (September, 1055), 22-38. Also "Reticence: l"thology of the Nomal. Speaker," Speech Monographs, $35(9068) ; 39-49$.

3. Gerald M. Philips and David Butt, "Reticence Revisited," The Pernsytroina Sreech Annual, XXIII (September, 1966), 40-57.

4. Larry A. Steward, Attitudes Toward Commication: The Content Nolysis of Interviews with Jight Reticent and light NonReticant collere Students (Urmublished Ph. D. Jissertation, The Pemsylanta State Universjty: Injversity Park, Pa., 1968).

5. Theodore S. Hopf, "Reticence and the Oral Interpretation Teachex," Tise Speech Teacher, XIX (November, 1970), 268-271.

6. Willian K. Ickes, "A Classical Conditronne Model for

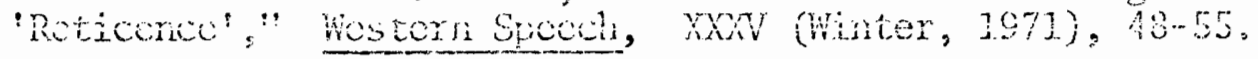

7. Janice 1). Bush and John R. Bittner, "The Effect of the Video-Tape Recorder on Jevels of Arxiety, Exhibitionion, and Reticence," (Uipubijished paper presented at the Speech-Communication Association Naticnal Convention: New Orleans, Ja., 1070).

8. Clarence 1. Barrhart (ec.), American College Encyclopedic Dictionary (Chicago: Spencer Press, 1950), 1036. Cited in Mij $\mathrm{r}$, cit. : p. 2 .

9. Charles Van Riper, Speech Correction: Principles and

Methods (Englewood Cliffs, N.J.: Prentice Hall, Inc: 1963). Cleed in luir, op. cit., p. 2 .

10. Mis, op. cit., p. 2 .

11. Ibid., p. 93.

12. Ibicl. p. 95 .

13. Eugene T. MacJonald, "A Study of Sone factors Related to Conversational Ability," Speech Monographs, XJI (1945). Cited in Niir, op. cit. p. 95.

14. Mir, op. cit., p. 96.

15. Lbic., p. 29. 
16. Ibid., p. 93.

17. Ibid., pp. 30-32. Cited in Steward, op. cit., pp. 102-103.

18. Muir, op. cit., p. 96.

19. Ibid.

20. Steward, op. cit., p. 87 .

21. Muir, op. cit., p. 96.

22. Sceward, op. cit., pp. 41-51.

23. Philips (1968), op. cit.

24. Mir, op. cit., p. 96.

25. Ibid.

26. Ibid.

27. Ibid, p. 97.

28. Stovard, op. cit., p. 105.

29. Muir, op. cit., p. 98.

30. Ibid.

31. Ibid.s p. 99.

32. Ibid., p. 98.

33. lbid., p. 99.

34. Ibid., pp. 104-105.

35. Steward, op cit., pn. 106-107.

36. Phillips (1965), oj. cit., p. 28.

37. Ibid.

38. Ibid., p. 31 .

39. Ibid.

40. Ibid., p. 32

41. Jbid., p. 36. 
42. Phillips and Butt, op. Eit., p. 40.

43. Ibid.

44. Ibic., p. 42.

45. Ibj.d., p. 46 .

46. Theodore S. Hopf, Unpublished Manuscript, Summer, 1966. Cited in Steward, op. cit., p. 4.

47. Steward, op. cit., p. 5.

48. Ibid, p. 132.

49. Ibid., p. 41.

50. Ibid., p. 43.

51. Ibid., p. 46.

52. Ibja., $\mathrm{p} .135$.

53. Ibid.

54. Ibid., p. 50.

55. Ibid., p. 73.

56. Ibid., p. 43.

57. Ibid., p. 49.

58. Ibid., p. 135.

59. Ibid.

60. Ibid., p. 86.

61. Ibic., p. 85.

62. Ibid.

63. Ibid., p. 3.

64. Ibid., p. 133.

65. Ibjd.

66. Ivid, p. 139 .

67. Ibid., pp. 139140. 
68. Phillips (1968), op. cit., p. 39.

69. Ibid., pp. 39-40.

70. Ibia., p. 40.

71. Ibid.

72. Ibid., p. 41-42.

73. Ibid., p. 43.

74. Ibid., p. 40 .

75. Hopf (1970), op. cit.

76. Ickes, op. cit.

77. Hopf (1970), op. cit., p. 271.

7i. Ickes, op. cit.

79. Ibid., p. 49.

80. Tbid., p. 51.

81. Ibid., p. 55. Italics inine.

82. Steward, op. cit. -

83. Bush and Bittner, op. cit.

34. Ibid., p. 7.

85. Muir, op. cit.

86. Steward, op. cit.

87. Fhillips (1.968), op. cit. 


\section{CHAPTER III}

\section{PROBLEM AND PROCEDURES}

\section{GENESIS GF THE PROBLEM}

The impetus for the present study was the realization that no controlled comparisons of the communicative behavior of reticent and non-reticent individuals has ever been attempted. Indeed, unitil recently all of the information about reticent individuals has been oiltained in situations in which the reticent subjects evaluated their own conversational abilities.

The stuđies by Muir ${ }^{1}$ and Steward ${ }^{2}$ are based upon a content analysis of interviews in which reticent subjects discussed their perceptions of their communicative abilities. Similarly, the "R" (for reticence) scale developed by Phillips and Erickson ${ }^{3}$ also relies upon self-disclosure to classify subjects.

The assumption in all these instances is that the communication behavior reported by the individual corresponds to his actual conmunicative behavior. Yet this notion has never been tested, and consequently no alternative measures of assessing the accuracy of the subject's assessment of his ow communicative ability presently exist.

A second reason exists for an examination of the behaviors of reticent subjects. The Review of the Literature revealed that all of the samples studied were drawn from a college student population. In order to generalize to another age group, such as an elementary or 
secondary school population, it would be necessary to derive new population norms. Inferences about these other populations are very difficult to make on the basis of the existing knowledge of reticence. The problem is compounded when we consider that certain groups, particularly those in the elementary school level, may not be amenable to the interview techniques. Yet it is important to know when, how, and to what degree the phenomenon of reticence develops, if preventive measures are to be considered.

One of the ways to acquire this information is to iet the subject's action in a communicative situation form an altemative measure for those measures in which the subject is asked to assess his own actions. Although a primary objective in all reticence studies has been to "isolate behavior which might be characteristic of reticence," 4 no controlled observations of actual comiunicative behavior have yet been undertaken.

\section{RATIONALE FOR THE APFROACH}

Communication behaviors can only be observed when slabjects are engaged in communication. This study is therefore focussed on an observation of certain behaviors which seem likely to occur when reti.cent subjects are engaged in communicative interaction. Yet the public platform is not the proper setting, since any observable differences obtajnea in that context could be attributable either to stagefright (a differentiated behavior comon to inexperienced public speakers) or reticence (a behavior undifferentiated as to the coitext in which it cccurs). In order to eliminate the stagefright variable 
and reduce the possibility that speech fears have been urnaturaliy amplified by the structure of the situation, this study will focus on an analysis of the interactive behaviors common to reticent subjects participating in face-to-face small group communications.

\section{STATEMENT OF THE PROBLEM}

The specific problem to be investjgated is as foilows: In what ways and to what extent are the interactive profiles of task groups with reticent members sinilar to each other in the amount and distribution of task and social-ernotional acts, and to what extent are they different from the groups with no reticent nembers?

For the purposes of this stucy, the "reticent renber" is defined as a person for whom apprehension about nerticipation in oral conmunication consistently outweighs his projection of gain fron the situation. The non-reticent mertber is one who may experience apprehension about communicative situration: but who is aware that he has the capacity to reduce tension and engage in effective coimunication when the need arises. These definitions are in agreement wi.th those of Hopf ${ }^{5}$ and Phillips. ${ }^{6}$

\section{HYPOTHESES TO BE TESTED}

There exists conflicting evidence for specific hypotheses concerning the probable communicative behavior of the reticent subjects, including their effects on the groups in which they interact. Previous investigators of reticence have defined the reticent population in terms of their disposition to remain silent, as well as their tendency 
to refrain from any socializing or cormunicative behavior. Steward further reports that the reticent subjects reported "mininal or no comnunicative contact beyond the utility level with adults outside of the immediate family." 7 Conversely, all of the non-reticents in Steward's study reported highly favorable and valued relationships with persons outside of the immediate family.

These findings seem to indicate that differences should be evident in a comparison of the interactions of groups with reticent members and groups with no reticent menbers particularly with respect to the number and distribution of acts initiated by the various groups.

In contrast to this evidence, Steward remarks that "observation of behavioral characteristics offers little for purposes of discrimination between the reticent and the non-reticent individuals." 8 That is, situations occur in which manifestations of speech fears and other maladaptive behaviors to the communicative situation are quite normal responses frequently generated by unfamiliarity and lack of knowledge concerning behavicr in the situation. While Steward's remarks are not based on a controlled cbservation of reticent behavior, they do lend some support to the null hypothesis (Hypcthesis III) which this study is trying to test.

The following hypotheses will bo tested:

Hypothesis I: The groups with roticent members will have a significantly smaller total of all acts initiated than will the groups with no reticent members . 
Hypothes is IT: Within the grouns with reticent mernbers, the reticents will address significantly more acts to non-reticents than to other reticents. iypothesis III: In a cormaxison of groups with reticent members and groups with no reticent menibers, there will be no significant differences in the acts scored in the varicus categories of the interaction analysis. Hypothesis I has been formulated from the description of the reticent as a person with a disposition to remain silent and to avoid the comnunicative situation. This disposition should be evident fron an observation and comparison of the total number of ccmmunicative acts which are initiated by the reticent and the ron-reticent groups.

Hypothesis II is derivable from the fjrst hypothesis when we consider the nature of the communicative interaction. The pattern of communication is predictable to sone degree simply becalise as Bales says,

Persons in interaction apparently tend to naintain a logical and interpersonal congruity in interaction sequences. Acts do not occur in isolation, but in sequences in which actions are made in anticipation of reactions, and reactions are made in reference back to preceding actions. ${ }^{9}$

In terms of the kinds of distinctions measurable by the categories in Bales' system, a numer of predictable patterns usualiy occur. Questions tend to elicit answers: answers tend to elicit agreement or disagreement; jokes tend to elicit laughter; and so on tinroughout the categcries. In essence, all comunicative interactions consist of a pattem of action-and-reaction sequences.

Because acts do not occur in isolation, a tendency exists to direct all reactions to the person initiating the act. Thus a large 
number of acts initiated by the reticents will be in response to acts directed toward them. Now if, as Hypothesis I predicts, the reticent indivicuals initiate a smaller number of acts (compared to the nonreticents), the conclusion must be drawn that the reticents will more readily address acts to non-reticents than to other reticents.

No predictions conceming specific differences in the categories of the interaction analysis is warrented by the previous studies. However, the possibility exists that the predicted differences in the amount and direction of interaction will cause corresponding differences in various categories of the interaction analysis. It is for this reason that Hypothesis III has been presented as a null hypothesis.

\section{DEFINITION OF TERMS}

In order to specify the way in which certain terms will be used within this study, they will be defined in this section.

1. Act. A single unit of interaction. The smallest discernable segment of verbal or nonverbal behavjor which can be classified under the experimental conditions of serial scoring.

2. I.P.A. Interaction Process Analysis - The system of interaction analysis devised by Robert F. Bales.

3. Interactive Profile. The distribution of interactive "events" (acts) scored by raters ir Robert F. Bales' Interaction Process Analysis.

4. Non-Reticent ("NR") Groups. The three experimental groups containing no reticent members (i.e., "normal" or "control" groups). These will be designated as NRI, NRIT, and NRIII. 
5. Reticent ("R") Groups. The three experinental groups containing two (out of forr) reticent members. These will be designated RI, RII, and Rĩi.

\section{ASSUMPTIONS CONCERNING TMTERACTION ANALYSIS}

The following is a clarification of the investigator's assumitions concerning Interaction Analysis and the interaction sequences. Any attempt to define similarities and differences between groups of individuals must be founded upon an investigation of the area in which the differences are expected to occur. In the present study, differences are expected to occur between reticent and nonreticent groups in the nunber and nature of their conmunicative interactions. Instruments which would measure cormunication of various kinds were therefore sought. The method selected was the application of a system of systematic observations derived by Robert F. Bales and known as Interaction Process Analysis. Thus the relevart areas are expressed as categories and sub-categories employed in the Interaction Analysis which in turn provide the basis for the observations.

To describe and classify the different behaviors which are present in the process of interaction, Simon and Boyer indicate that. a system needs to meet three requirements:

First, it must be descriptive as opposed to evaluative, and, although it can be used to analyze emotional or evaluative situations, the language itself must be descriptive of the values or feelings being discussed.

Second, the language must deal with what cas be categorized or measured, and 
Third, it must deal with snall bits of action or vehavior rather than with global concepts.10

The type of observation system which meet these requirements have come to be known as systems of "interaction analysis." Interaction analysis in its broadest sense may be defined as a method of describing and interpreting human interaction as it occurs in a particular group setting. Similarly, interaction may be defined as the behavior of one person intluencing the behavior of another in a faceto-face situation. Although the term "interaction analysis" was first used to describe interactive behaviors in task-oriented small groups, Amidon ${ }^{11}$ indicates that the term has since been applied to a variety of interactive situations.

Interaction Process Analysis is a phrase first used by Bales ${ }^{12}$ to describe a standarized method of simultaneously classifying human interaction in terms of the quality of the act, who performs it, and in relation to whom. The term is meant to distinguish the method from various modes of "content analysis." The interaction categories do not classify what is said (the content of the message) but rather how the persons communicate, that is, the who-does-what-tc-whom dimensions in the process (time order) of their interaction. An examination of the titles of the categories, and their recinrocal references to each other, will clarify these points (see Figure 1).

To say a person "gives opinion" (category 5), for example, does not tell what the content of the opinion is; or to say that a person "cisagrees" (category 10) is not to say what he disagrees with in terms of the idea content. This general distinction holds true for all twelve categories in the Interaction Process Analysis system. 
They are ail concerned with the forn of the interpersonal comr. munication, rather than j.ts specific content.

\section{INTERACTION GFOUENCES}

The twelve categories shown in Figure 1 seem to suggest the back-and-forth nature that is characteristic of normal conversation. and social behavior. A casual observaticn of normal interaction provides a simple validation of the truisms implied by the categories. When a person asks a question, he tends to receive an answer from somebody else; when one attempts to give an answer, he receives a reaction, either positive or negetive. Bales identifies other kirds of interactive pattems and links then to specific persciality "types" by explaining that

Some persons seldom attempt answers to group problens, but seem rather to specialize in listering and giving positive reactions, whereas others seem to specialize in negative reactions and counter-arguments. Every so often a joke appears - a mixed action, neither clearly uositive nor negative, but some of bo'h, and it is followec by a jagh. The group then often goes into a short period of joking and laughing, before they get back to the serious business represented by giving opinion. In non-task periods there is often a good deal of information and friendly behavior, interspersed with dramatizations, jokes, and laughs. This often happens both before and after the more serious taskoriented part of the session. 13

The structure of the Interaction Process Analysis system is built on a very simple comnon-sense base, and much that one intuitively believes about everyday conversation can be confimed by it. The amazing thing, perhaps, is the depth at which it reveals the basic attitudes of people, their personalities, and their positions in a group. This is simple because people do not pay much attention to 
Positive

(and mixed)

Actions

A. Social-Emotional Area:

1. Shows solidarity ( $\left.\mathbf{I}^{*}\right)$

2. Shows tension release $\left(\mathrm{e}^{*}\right)$

3. Agrees $\left(\mathrm{d}^{*}\right)$

Attempted

Answers

B. Task Area:

4. Gives suggestion (c*)

5. Gives opinion (b*)

6. Gives orientation $\left(\mathrm{a}^{*}\right)$

Questions

C. Task Area:

7. Asks for orientation (a:

8. Asks for opinion (b*)

9. Asks for suggestions ( $\left.c^{*}\right)$

Negative

(and mixed)

Actions

D. Socia1-Emotional Area:

10. Disagrees $\left(\mathrm{d}^{*}\right)$

11. Shows tension $\left(e^{*}\right)$

12. Shows antagonism (f*;

*Key: a, problems of cormunication;

b, problems of evaluation;

c, problems of control;

$d$, problens of decision;

$e$, probjems of tension-reduction;

$f$, problems of reintegration.

Figure 1. Categories for Robert F. Bales' Interaction

Process Analysis system. 
the form of their interaction, nor do they have much control over it. People are usually more attentive to the content of what they are saying. But they unintentionaliy convey much in their manner, and this is intuitively understood by most of their listeners.

The subtle yet differing sequerces which are regularly employed in interpersonal commications are highly indicative of differences in the individuals who participate in the communication. The diagnostic power of interaction Process Analysis depends upon the assunption that quantitative differences in the normally existing relationships between the categories of interaction is related to a qualitative difference in the personalities or context in which the interaction occurred.

In terms of the present study, since the context of the interaction was held constant for all subjects, hypotheses were generated attributing interactive differences to the personality variables inherent in the reticent/non-reticent subject classification system.

\section{POPULATION AND PROCEDURES}

Twenty-eight subjects in al1, eight reticent and twenty nonreticent, were selected from the population of students enrolled Spring Term, 1971, in Speech 111, the beginning course in Fundamentals of speech at Portland State University. The twenty-eight subjects were diviujed into seven groups of four members each. Three of the groups composed the experimental variable and consisted of two reticent and two non-reticent members in each group. The control groups consisted of three four-person groups selected from the non- 
reticent population. The data from the remaining group, consisting of two reticent and two non-reticent members, had to be rejected because of a failure on the part of one of the non-reticent members to appear at the appointed meeting place. 14 Thus the total number of groups was held to six: three experimental and three control groups. Each of the six groups consisted of four subjects, two subjects from each of two Speech 111 sections.

Reticent subjects were selected on the basis of their performance on the "R" Scale, an instrument designed by Phillips and Erickson 15 to measure "Speech Fears." The test is normally administered to all registrants for Speech 111 at the beginning of each term. Students who score over one standard deviation above the mean for those taring the test in previous terms are eligible to be considered for transter into a special section designed specifically for those with unusualiy high degrees of apprehension associated with the speech act. Final disposition is made following an interview with members of the staff who administer to the special. classes. Only eight students were enrolled in the special section during the term in which this experiment was undertaken.

After several weeks of classroom contact with the students, the Instructor, Mr. Robert Harvey, was consulted to determine which students were both reticent and likely to participate in this study. It was then decided that, since the available reticent population was so small (only eight), all of the subjects should be utilized. The instructor therefore agreed to use this experiment in lieu of a unit in "small group conminication:" and required that ali participate 
at a time convenient to them.

Non-reticent subjects were seiected from the regujar: Speech 111 classes of: Dr. Stephen h́osokoff and Mrs. Carolyn Young. Arther securing a copy of the students' time schedules, it was ascertained whicli schedules coincided with those of the raters and the other students. The students who were thus selected were asked to participate in this experiment. They were told by their instructors of the opportunity to fulfill the requirenents for an assignnent by participation in the proposed group interaction. AIl who were asked to participate agreed to do so.

Potential subjects, both reticent and non-reticent, received an in-class reminder froin their instructors a day or two preceeding their scheluled participation in this experiment. Those who could not be contacted in this manner were reached that evening by telephone.

Raters were trained by this experimenter with the assistance of Professor Theodore Grove. The training consisted of approximately five hours of practice per week for a total of fifteen weeks.

Al1 six of the group interactions took place during the Spring, 1971 term. Each group was scheduled for a single neeting, fifty minutes long, during which time the experiment took place. The procedures followed in this study included several steps which are listed below.

1. Students were selected in the manner described above and invited to participate in the experiment. Those willing were informed of the date and time the experiment was to begin. 
2. Upon arrival of the subjects, they were seated in semicircular fashion facing a one-way observation mirror. Each experimental group contained four members, two male and two female. For the reticent groups, one of the majes and one of the females was reticent. Raters, however, were not inforned which subjects were reticent and which were non-reticert, ror were they informed which groups contained reticent memers and which did not.

3. Each group then participated in a fifty-minute discussion, the purpose of which was to solve tro problems using group consensus. The oraer of the problens was randomized for each groun, and all sessions were tape recorcied.

4. Data were collected by three raters for each group. Two raters anaiyzed the interaction in terms of the twelve categories in Bales' Interaction Process Analysis system, while the third rater collected the who-to-whon sequences in the interaction.

5. The data were subjected to statistical analysis in order to fumish the necessary interpretations.

\section{RATIONALE FOR THE PROCEDURE}

Two limiting factors, the number of available subjects and the degree of inter-rater reliability, served as the basis of the rationale for the approach selected.

The rationale for selecting the number and composition of the varjous experimental groups was based on the small number of reticent subjects available for this study. Although considerably more students ordinarily enroli in the reticence section, oniy eight were enrolled 
during the period in which the axperiment was conducted. This number prohibiced designing groups with moxe than four persons and groups containing all reticent subjects.

The level of inter-rater reliability also served as an important factor in this study. Although it would have been informative to have had the who-to-whom sequences in the interaction keyed to the various acts, thereby permitting an analysis of the kinds of acts generated by each individual, it was unfortunateiy necessary to simplify the raters' tasks in order to increase the inter-rater reliability to a significant level. Preliminary reliability tests, before the simplification of tasks, were exceedingly icw, hovering about 19 percent. After the task simplification, the pretest reliability for the raters averaged 64.1 percent, white the overall avsage of the six experinental sessions was 66.6 percent.

Reliabili.ty was computed according to Scott's ${ }^{16}$ method. His method, according to Flanders, is "unaffected by low frequencies, cari be adapted to percent figures, can be estimated more rapidly in the field, and is more sensitive at higher levels of reliability, ${ }^{17}$ than is Bales' ${ }^{18}$ suggested adaptation of the chi-square. A thorough discussion conceming the calculation of reliability by Scott's method can be found in rlanders.

\section{RATIONALE FOR THE TASK}

The rationale adopted in selecting the group tasks is similar to that adopted by Bajes and Couch ${ }^{20}$ in their study of the processes of interaction. Their findings indjcate that the use of "human 
relations cases" proved to be a task that was sensible to the participants and did not obviously require some particular type of previous experience, ability, ox technical knowledge. "Participants generally become involved, talked easily, often argued, and sometimes became angry with each other."21

Because the nature of the hypotheses indicated expected differences on the social-emotionai factors of the interaction analysis, j.t was deemed advisable to select as the group tasks problems which would evoke the emotional commitment necessary for the differences to evidence themselves.

One of the group tasks, the NASA Group Consensus Problem (see Appendix B), called for a scientific orientation, while the other task, The Grievances of Black Citizens Consensus Problem (see Appendix C) necessitated a social-psychological orientation. Thus in the NASA problem giuestions such as "ilow can you use injection needies in a space suit?" were raised and dealt with by the various groups, while the second task above the discussion centered around the assumed prioritjes of the minority group being studied. Taken together, the two problems provided a wide latitude in which the discussion could roam. This allowed the widest possible opportunity for each person to participate fully.

\section{XI . LIMITATIONS}

All behavicral studies conducted within a laboratory setting are limited in the generality of their observations. This study is not excluded from this limitation. The subjects are placed in 
an umatural setting. Unseen observers, of whom the subjects are aware, serve as silent members in the commicative situation. Group pressures to converse place certain demands on them, and they are likely to be overly conscicus of what is being said. Asking the subjects to discuss specific tasks further adds to the unnatural setting.

The study is also Iinited in the population from which the subjects were chosen. They were college students attending a university in Portland, Oregon, and who also were taking a beginning course in Speech. In addition, subjects were limited to Caucasian Americans. All foreign students and those of American subcultures (Black, Mexican, Indian, Puerto Rican, and Oriental Anericans) were not included in the sampiing. Afurther limitation is placed on the reliability with which the reticent subjects were selected. The ' $R$ ' Scale, the principal measuring instrument employed, maintains only face validity. Subjects from one university in a particular locale were chosen because of converience. The size of the sample and the college classes from which it was drawn were similarly chosen. Time has also been a limiting factor in this study. Conclusions will therefore be drawn with these limitations in mind. 
Notes

1. Frances Laura Muir, Case Studies of Selected Exampies of Reticence and Fluericy (Unpublished Master's Thesis, Washington State University: Pullman, Washington, 1964).

2. Larry A. Steward, Attitudes Toward Communication: The Content Analysis of Interviews with Eight Feticent and Eight Non." Reticent College Students (Unpublished Ph.D. Dissertation, The Pennsylvania State University: University Park, Pa., 1968).

3. Gerald M. Phillips and Eugene E. Erickson, "'R' Scale," Washington State University: Pullman, Washington, 1.964. Cited in Theodore S. Hopf, "Reticence and the Oral Interpretation Teacher," The Speech Teacher, XIX (November, 1970), p. 270 .

4. Muir, op. cit., p. 93.

5. Theodore S. Hopf, Unpublished Manuscript, Summer, 1966. Cited in Steward, op. cit., p. 4.

6. Gerald M. Phillips, "Reticence: Pathology of the Normal Speaker," Speech Monographs, 35 (1968), p. 40.

7. Steward, op. cit., p. 135 .

8. Ibid., p. 3 .

9. Robert F. Bales, Personality and Interpersonal Behavior (New York: Holt, Rinehart, and Winston, 1970), pp. 81-82.

10. Anita Simon and E. Gil Boyer (eds.), Mirrors For Behavior: An Anthology of Observation Instruments (Philadelphia, Pa.: Research For Better Schools, Inc., 1970), Volume 15, p. 1.

11. Edmund J. Amidon, "Interaction Analysis," in Philip Enmert and William D. Brooks (eds.), Methods of Research in Communication (Boston: Hougliton Mifflin, 1970), p. 373 .

12. Robert F. Bales, Interaction Process Analysis (Cambridge, Mass.: Addison-Wesley, 1950).

13. Robert F. Bales (1970), op. cit., p. 95.

14. A subsequent check with his instructor revealed that his atterdence in class was also sporadic.

15. Phillips and Erickson, op. cir. 
16. William A. Scott, "Reliability of Content Analysis: The Case of Nominal Coding," Public Opinion Quarlerly, 19 (Fal1, 1955), $321-325$.

17. Ned A. Flanders, "The Problems of Observer Training and Reliability," in Edmind Amidion and John B. Hough, Interaction Analysis: Theory, Research and Application (Reading, Mass.: AddisonWes1ey, 1967, p. 151.

18. Bales (1950), op. cit., p. 104.

19. Flanders, op. cit.

20. Robert F. Bales and Arthur S. Couch, "The Value Profile: A Factor Analytic Study of Value Staternents," in Bales (1970), op. cit., p. 492-510.

21. Ibid., pp. 492-493. 


\section{CHAPTER IV}

\section{RESULTS}

It is the purpose of this chapter to present the results of the study. First to be assessed will be the impact which the varying group problems had on the ciscussion content being investigated. Following this, the three research hypotineses will be presented, along with a statistical interpretation, ${ }^{1}$ Chapter $V$ will summarize and interpret these findings.

Wilcoxon matched-pairs signed-ranks tests were used to deternine the effect of the two group problems on the discussion content being investigated. The first two hypotheses utilized onetailed $t$ tests in their interpretations, while the remaining hypothesis used a non-directional chi-square test in the analysis. Tables will be shown for all data listing the observations, expectations, and final results of the statistical tests which were employed.

Seven Wilcoxon matched-pairs signed-ranks tests, equated for total acts per group, were utilized to determine the effects attributable to the two group problems. The data were initially analyzed in their entirety, and the two complementary halves (i.e., task and social-emotional) were then investigated. These two halves were followed by an analysis of their respective subdivisions .. "questions" and "attempted answers" for the task area and "positive" and "negative" actions for the social-emotional area.

The null hypothesis for effects of the task variable failed to 
be rejected. No significant differences were revealed at the .05 levei in the seven analyses computed. With $n=6$, the .05 level required a $T=0$ for significance. The values obtained were considerably higher, ranging from 9 to 10.5 . There are no significant differences in the interaction profiles due to differences in the two group problems utilized in the discussion. Therefore data were pooled across tasks in all subsequent analyses. Table $I$, below, summarizes the results of these analyses.

TABLE I

SUMMAKY OF SEVEN WIICOXON MATCHED-DATRS SIGNED-RANKS TESTS FOR TASK EFFECTS ON GROUP INTERACTIVE PROFILE

Wilccxon ' $\mathrm{T}$ '

Total Acts $10^{*}$

Task Orientation $9 *$

Social-Emotional Orientation. $10^{*}$

"Questions" $10^{*}$

"Attempted Ariswers" $9^{*}$

"Positive Actions" $10 *$

"Negative Actions" $10.5^{*}$

Note: For al1 tables in this chapter, significance will be indicated in the following manner: (*) not significant at the .05 1eve1; $(* *)$ significant at the .05 level; $(* *)$ significant at the .0011 level.

Hypcthesis 1: The groups with reticent menbers will have a significantly smaller total of all acts jnitiated than wi1.] the groups with no reticent members. 
A one-tailed $t$-test for differences between independent means was usea to test for differences in the total number of acts initiated. No significant differences were revealed at the .05 level. At four degrees of freedom, a $t=2.132$ is necessary for significance at the .05 level. The value obtained, .442, was considerably lower, jndicating the almost negligible difference between the means of the two types of groups. There are no significant differences in the total number of acts initiated by groups with reticent nembers and groups with no reticent members. Table II, below, indicates the basis for this finding.

TABLE II

t-TEST FOR TOTAL ACTS INITIATED

\begin{tabular}{ccccccc}
\hline Comparison & $\mathrm{N}$ & d.f. & $\mathrm{m}_{1}-\mathrm{m}_{2}$ & $\mathrm{~s}^{2}$ & $\underline{\mathrm{t}}$ \\
\hline R Groups - NR Groups & 6 & 4 & 46.66 & 16695.68 & $.442^{*}$ \\
\hline
\end{tabular}

Hypothes Is II: Within the grolips with reticent nembers, the reticents will adiress significantly more acts to non-reticents than to other reticents

To test Kyoothesis II, the raw data were simply observed. Since it was found that the mean for reticent subjects taiking to other reticent subjects was slightly higher than the mean for reticents talking to non-reticents, the hypothesis was rejected. It should be noted that, since there are two non-reticent subjects in each group while only one reticent subject in each group with whom the reticent 
potentially nay jinteract, the expected frequency would be $2: 1$ in the direction of reticents taiking more to non-reticents. In order to equalize for this expected frequency, the tallies for reticents talking to non-reticents were halved (i.e., "averaged"). The results indicate that there are no significant differences in the number of acts reticent subjects address to other reticents and non-reticents. These resuits are illustrated in Table III.

\section{TABLE III}

FAW SCORES FOR NUMBER OF ACTS RETICENT SUBJECTS ADDNESSED TO OTHER RETICENTS AND NON-REETICENTS

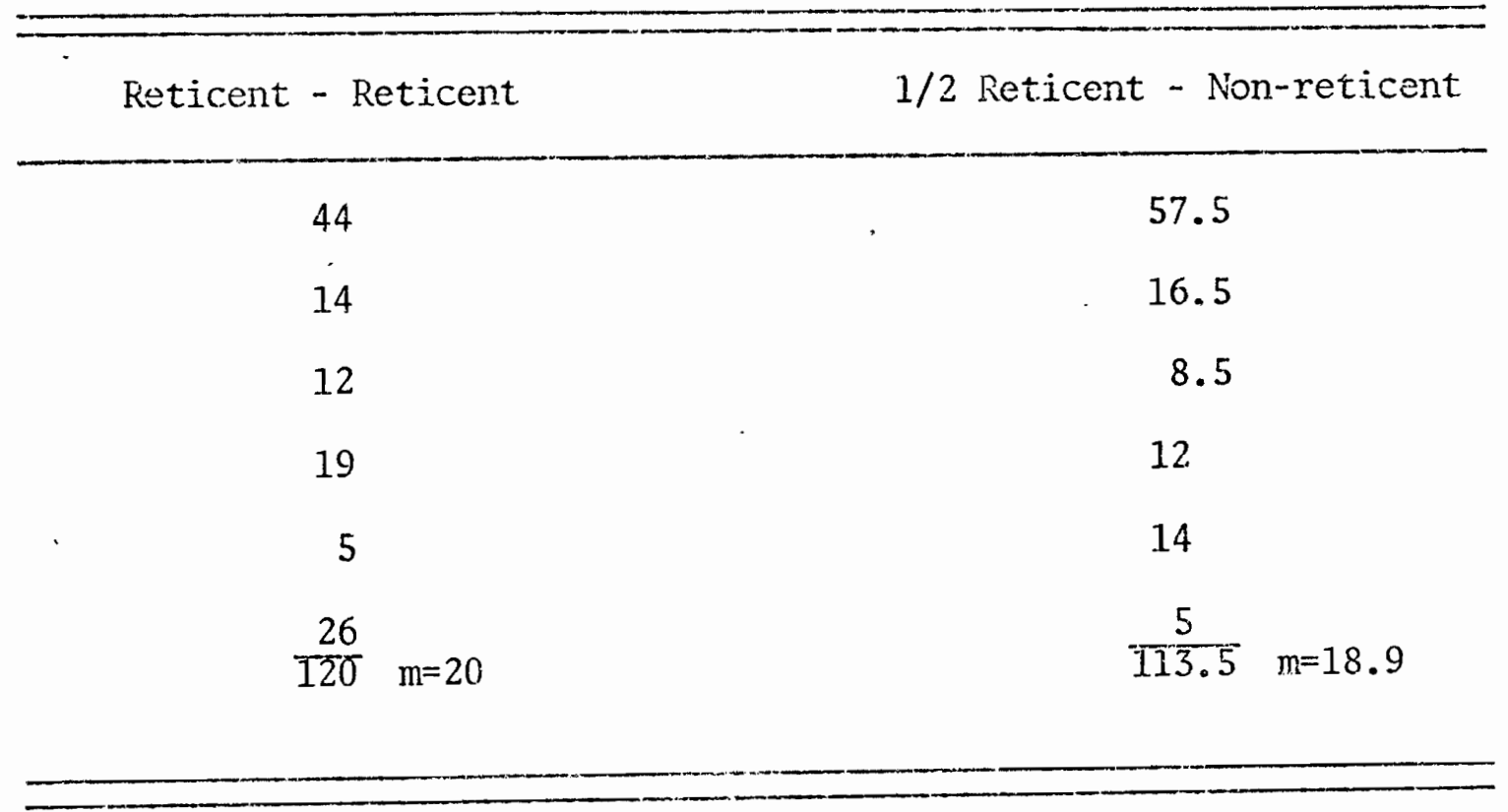

In an attempt to explain the results of the first two hypotheses, a $\underline{t}$ test for differerices between correlated means was employed to test the null hypothesis that there will be no significant differences in the amount of talking generated by reticent and non-reticent subjects. The findings indicate that, although non-reticents tended to talk more, 
the difference was not statistically significant at the .05 level.

A $\underline{t}$ score of .003 was obtained, while a value of 1.476 was necessary to reach the .05 level of significance. There are no significant differences in the amount of talking initiated by retjcent and nonreticent subjects. Tables IV and $\mathrm{V}$, below, indicate this finding.

TABLE IV

RAW SCORES FOR AMOUNT OF. TALKING INITJATED BY RETICENT AND NON-RETICENT INDIVIDUALS

\begin{tabular}{|c|c|}
\hline Reticents & Non-reticents \\
\hline 159 & 240 \\
\hline 45 & 228 \\
\hline 81 & 87 \\
\hline 72 & 76 \\
\hline 74 & 78 \\
\hline$\frac{60}{491} m=81.8$ & $\frac{20}{729} \mathrm{~m}=121.5$ \\
\hline
\end{tabular}

TABLE V

t-TEST RESULTS FOR AMOUNT OF TALKING INITIATED BY PETICENT AND NON-RETICENT INDIVIDUALS

\begin{tabular}{lcccccc}
\hline Comparison & $N$ & d.f. & $m_{1}-m_{2}$ & $s_{\mathrm{d}}$ & $\underline{t}$ \\
\hline Amount of talking & 6 & 5 & 39.7 & 32277.3 & $.003^{*}$ \\
\hline
\end{tabular}


Hypothesis III: In a comparijos of groups with reticent members and groups with no reticent members, there will be no significant differences in the distribution of acts scored in the various categories of the interaction analysis.

A $2 \times 12$ chi-square test of the nul1 hypothesis was employed to test for differences in the distribution of acts in the tweive interaction categories. An extremely significant difference was revealed $(p<.001)$, and the null hypothesis was rejected. At eleven degrees of freedom, the .001 level required for significance is 31.25. The chisquare cbtained was considerably higher at 105.12. This indicates that the distribution of total acts in grcups with reticent menbers differs significantly from that of groups with no reticent members. Table VI presents these results.

In order to ascertain the specific areas in which the above differences occurred, three $2 \times 2$ chi-square tests of the nuil hypothesis were then employed to test for differences between the following pairs of variables: "task and social-emotional," "questions and. attenpted answers," and "positive and negative."

The null hypothesis was rejected for the variable "task and social-emotional." A.cts scored in the various task and social-emotional categories differed at a very significant level with a chisquare of 11.2. To be significant at the .001 level with one degree of freedon, a chi-square of 10.83 is necessary. Differences therefore exist between the two types of groups with respect to their task and social-emotional profiles. 
TABLE VI

RAW SCORES FOR RETICENT AND NON-PETICENT GROUPS ACROSS

12 CATEGORIES OF BALES' I.P.A.

\begin{tabular}{|c|c|c|c|}
\hline & Category & $\mathrm{R}$ Groups & NR Groups \\
\hline 1. & Shows Solidarity & 2 & 2.5 \\
\hline 2. & Tension Release & 56 & 12.4 \\
\hline 3. & Agrees & 430 & 422 \\
\hline 4. & Gives Suggestion & 92 & 169 \\
\hline 5. & Gives Opinion & 1970 & 1764 \\
\hline 6. & Gives Oricntacion & 505 & 579 \\
\hline & Asks For Orientation & 1.2 .3 & 129 \\
\hline 8. & Asks For Opinion & 156 & 188 \\
\hline 9. & Asks For Suggestion & 14 & 27 \\
\hline 10. & Disagrees & 58 & 102 \\
\hline 11. & Shows Tension & 114 & 12.4 \\
\hline 12. & Shows Antagonism & $\begin{array}{r}4 \\
-\end{array}$ & 11 \\
\hline & TotaI & 3524 & 3664 \\
\hline \multicolumn{4}{|c|}{$x^{2}=105.12 * * *$} \\
\hline
\end{tabular}

The null hypothesis was similarly rejected for the variable "questions and attempted answers." With d.f.=1, the .05 level required a chi-square of 3.84 . The value obtained was slightly higher at 4.5 . The profile of acts scored in the "questions and attenpted answers" subdivision of the task category is significantly different for the two types of groups being imvestigated. 
The nill hypothesis was accepted for the "positive and negative" variable. No significant differences were revealed at the .05 level. To be significant with $d_{0} f_{0}=1$, a $p=3.84$ is needed. The value obtained, only 1.3, was considerably smaller than the necessary one. An analysis of the "positive and negative" area of the social-enotional categories does not successfully discriminate between the two types of groups. Tables VII through IX, below, substantiate these findings.

\section{TABLE VII}

CHI-SQUARE TEST FOR JIFFERENCES IN TASK AND SOCIAL-EMOTIONAL ACTS

\begin{tabular}{lccc}
\hline Category & \multicolumn{2}{c}{ Groups } \\
& Reticent & Non-reticent \\
\hline Task Acts & 2860 & 2856 & $\mathrm{X}^{2}=11.2^{* * *}$ \\
Social-Enotional Acts & 664 & 808 & \\
\hline
\end{tabular}

TABLE VIII

CHI-SOUARE TEST FOR DIFFERENCES IN POSITIVE AND NEGATIVE SOCIAL-EMOTTONAL ACTS

Category

Groups

Reticent Non-reticent

Pos. Social-omotiona1

488

Neg. Social-emotional

176

571

237

$\mathrm{X}^{2}=1.3^{*}$ 
TABIEE IX

CHI. SQUAPE TEST FOR DIPEERENCES IN "QUESTTONS" AND "ATTEMPTED ANGSERS"

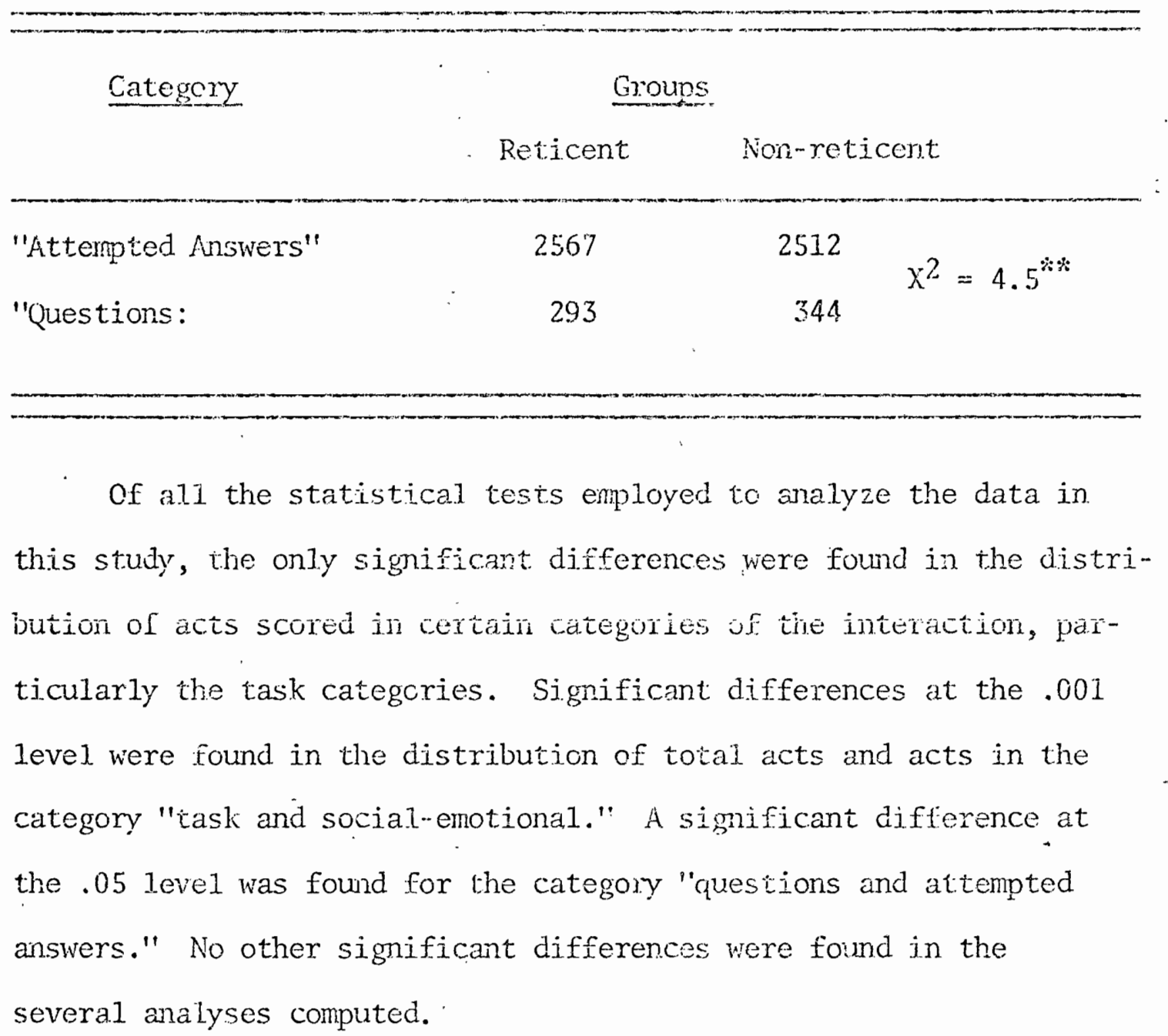


Notes

1. Statistical interpretations for the Wilcoxon matched-pairs signed-ranks tests and the chi-square tests were based upon:

Sidney Siegel, Nonparametric Statistics for the Behavioral Sciences (New York: McCraw Hill, Inc., 1956). Statistical interpretations for the $t$ tests were based upon Quinn McNemar, Psychological Statistics (New York: John Wiley \& Sons, 1955). 


\section{CHAPTER V}

\section{SUMMARY AND CONCLUSIONS}

This final chapter will surmarize and interpret the experimental results of the study. The research hypotheses will be reviewed, relevant resuits will be restated, ard conclusions drawn. Suggestions for further research will conclude this chapter.

\section{SUMMARY OF THE INESULTS}

The specific question which this question was designed to investigate was: In what ways and to what extent are the interactive profiles of task groups with reticent menbers similar to each other in the amount and distribution of task and social-emotional acts, and to what extent are they different from the groups with no reticent members?

The study was based on the assumption that the subtle yet differing sequences which are regularly employed in interpersonal communications are highly indicative of differences in the individuals who participate in the communication. In terms of the present investigation, hypotheses were generated attributing interactive differences to the personality variables inherent in the reticent/non-reticent subject classification system.

First to be assessed wore the differences in the interactive profiles attributable to the two group tasks used in the discussion. No significant differences were revealed. Thus it was ascertained 
that the uniqueness of the group tasks was not a significant factor in the subsequent anaiysis of the hypotheses.

Hypothesis I: Groups with reticent members will have a significantly smaller total. of all acts initiated than will the groups with no reticent members.

Hypothesis I failed to be confirmed. There are no significant differences in a comparison of the total number of acts initiated by the groups with reticent members and the groups with no reticent members. An explanation of this result lends itself to one of three alternative explanations: (a) within the reticent groups, reticent members initiated a smaller number of acts, while non-reticent members initiated proportionately greater numbers, thlis equalizing the total number of acts initiated; (b) contrary to all expectations, the reticent menbers initiated a greater number of acts, while non-reticent members initiated proportionately fewer; (c) reticent and non-reticent members initiated approximately equal number of acts.

Because of these possibilities, a test was made for significant differences in the amount of talking initiated by reticent and nonreticent subjects. A statistical analysis was employed, the result of which offered evidence for the acceptance of the latter choice. No significant differences were found. It can therefore be concluded that no differences exist in a comparison of the number of acts initiated by the reticent and the non-reticent subjects, nor are there differences in a comparison of the total number of acts initiated by the reticent ard the nor-reticent groups.

Hypothesis Ir: Within the groups with reticent members, the 
reticents will address simificant1y more acts to non-reticent than to other reticents.

This hypothesis was also unsubstantiated. There are no significant differences in the number of acts reticent members address to non-reticents or other reticents.

This finding, alung with those under Hypothesis I, reveals that the reticent person initiates the same number of acts as the non reticent person. Thus, at least for the variables discussed above, the reticent subjects interact in much the same way as the non-reticent subjects.

typothesis III: In a comparison of groups with reticent members and groups with no reticent members, there will be no significant differences in the distribution of acts scored in the various categories of the interaction analysis.

This analysis successfully discriminated between the two types of groups with respect to differences in the distribution of totai acts, as we11 as in the distribution of "task and social-enotional" acts. Groups with reticent members had a higher percentage of task acts and a correspondingly lower percentage of social-emotional acts than the non-reticent groups. A further breakdown of the "task and socialemotional" category revealed that differences also exist in the distribution of "questions and answers." Reticent groups asked fewer questions and gave more answers than the non-reticent groups. The "positive and negative" delineation of the "task and social-emotional" area revealed no significant differences along this dimension for the 
two types of groups investigated. These findings may indicate that differences were not found in the first two hypotheses simply because the groups with reticent members successfully aroided the areas of interpersonal difficulty. By "sticking to the task," reticent groups were able to avoid the social-emotional area and successfully complete the assignment without revealing any of the speech fears that had previousiy been reported on the ' $R$ ' Scale and in the preliminary interview.

In short, the findings in the present study reveal that, in the absence of precise measuring instrunents for reticence, it is virtually impossible to discein which students are truly "normal" and which are nerely nasking the more serious symptons of reticence. Although suble differences in the statistical anatysis were uncovered, it seens unlikely that those differences could have been noticed by the casual observer, indeed, the trained raters themselves were not able to differentiate between the reticent and the non-reticent subjects. In the only instance in which the raters were certain that they haci identified a reticent subject, a non-reticent group had been observed!

\section{CONCLUSIONS}

The results of this study have produced some highly significant , findings. The expected differences in the comparison of the anounts and direction of of reticent and non-reticent irteractions were not substantiated. In the light of these results, the conflicting evidence upon which the hypotheses were originally founded deserves discussion. 
Predictions concerning the probable communicative behavior of reticent students were based upon the definition of the reticent as a person with a disposition to remain silent and avoid communication. It was therefore expected that this proclivity would evidence itself in the present experimental situation.

Steward's counter-argment deserves restatement. He said that "observation of behavioral characteristics offers little for purposes of discrimination between the reticent and the non-reticent individual."1 Therefore, the concept of reticence "does not describe behavioral dimensions, but rather an attitude toward the self with regard to the comminicative act."2 Steward therefore explained that

this uncertainty concerning the meaning of behavioral characteristics is due to the prodigious capacity of human beings to hide, substitute, mask or otherwise deny front the observer evidences of symptons percejived by the individual to be socially unaccentable. ${ }^{3}$

An alternative explanation for the assumption that anxieties and speech fears were masked is that the tension, anxieties, and speech fears reported by the reticent suojects did not nanifest themselves in excessive proportions for the discussion tasks investigated. Previous investigations of the reticent studient may have placed him in an excessively threatening situation. Yerhaps the relatively unthreatening atmosphere of the small discussion group did not precipitate the overwhelming anxiety levels that would have been likely had the reticent subjects been asked, for example, to deliver a public speech. Even considering the conditions imposed by the laboratory setting, complete with strangers and a one-way mirror, it is safe to assume that the sna11 discussion groups were far less threatening than would 
be situations with similar laboratory conaitions but in which the reticent subjects were asked to give stand-up speeches. The infornality of the discussion groups may have lessened the threat-potential of the communicative situation.

Elements of masking, avoidance of threatening areas, and decreased anxiety due to the discussion situation are all presumed to have had effects of some unknown magnitude. Since all these possibilities tend to substantiate the notion that reticent students may be virtually unrecognizable from the population of normal students, the present discussion points to the advisability of adopting pedagogies applicable to the reticent student and implementing them in the traditional speech classroom.

IJI. SUGGESTIONS FOR FURTHER RESEARCH

Four areas of research, revealed during the course of this study, deserve prompt consideration. Each will be listed and discussed in turn.

1. Delineation of similarities and differences between those reticents characterized by their silence and those characterized by their verbosity. Although the highiy verbose person is characterized as reticent because his excessive talking serves as a means of avoiding any meaningful comminication, little is known of him. It is thought, perhaps, that underneath his facade he is much the same as the silent ones. Yet this similarity may belie many aifferences, just as the stutterer and the reticent may have similar uiderlying causes of their pathology while requiring quite different methods of diagnosis ana treatment. 
There is as yet no way to discern highly verbose reticent subjects from the normaily talkative person; the ' $R$ ' Scale, the usual measuring instrument employed, does not seem to delineate the verbose reticents. In fact, the only highly-verbal reticent subject in Steward's interviews of reticent and non-reticent subjects was obtained quite by accident. 4 The subject's sliccessful masking of his anxiety and avoidance behaviors through excessive verbalizations caused him to be recommended by his instructor as a non-reticent subject. The disparity between his conception of hinself as a communicator and his actual communicative behavior were only revealed after extensive interviews. This points to what may be the major difference between the silent and the verbose reticents. For the silent reticents, there at least seems to be congruity between the subjects' interpersonal behavior and their conception of themselves as communicators. For the verbose reticents, however, a disparity exists between word and deed.

2. Determination of the incidence and nature of reticent problens in the elementary and secondary school populations. Virtually nothing is known about the nature of reticence below the college level. If preventive measures are to be considered, this information is a necessity.

3. Development of pedagogjes applicable to the reticent population. This includes the as yet undefined populations in the elementary and secondary schoois. Clearly, reticent students are in need of specialized techniques designed to reduce perceived threat and therefore allow meaningful comminication to take place. Ideally, these sane technicues would be applicable to the population at Jarge. 
4. Develoyment of stanciardized measuring instrumerts for "reticence": and "attitudes toward comminication." A study by Justig and Ingram $^{5}$ revealed that no such staikdardized measuring instruments for communicative attitudes and abilities currently exist. Such an instrument ideaily would be useful with sub;ects having a wide range of educational backgrounds and communicative skilis. Perhaps reticence could be just one factor on a multi-dimensional test for attitudes and abilities with respect to oral communications.

Potential starting points for the development of such an instrument might include refinement of the techniques herein employed. The use of video-taping could be usefully employed both to increase inter-rater reliability and to pir down specific behaviors which are characteristic of reticence. In addition, the refinement of the various non-standardized measuring instruments currently available provides another area for future investigation. 
1. Iarry A. Steward, Attitudes Toward Conmunication: The Content Analysis of Interviews with Eight Reticent and Eight NonReticent Coi lege Students (Unpublished Ph.D. Dissertation, The Pennsyivania State University: University Park, Pa., 1968), p. 3.

2. Ibid., P. 133.

3. Ib $\underline{i d}$.

4. Ibid., pp. 251-259.

5. Myron W. Lustig and Glenr i. Ingran, A Search of Literature for Measuring Instruments in the Area of Oral Communication Skilis Tupulinsted manuscript prepared for the Northwest Regional Educational Laboratories: Portland, Oregon, 1971). 


\section{REFIRENCES}

Amidon, Edmund J. "Interaction Analysis." in Methods of Research in Communication. Edited by Philip Emmert and William D. Brooks. Boston: Houghton Mifflin, 1970.

Anidon, Edmund $J$. and John B, Hough, Interaction Analysis: Theory, Research and Application. Reading, Nass.: Addison Wesley, 1967.

Bales, Robert $F$. Interaction Process Analysj.s. Cambridge, Mass.: Addison Wesley, 1950 .

- Personality and Interpersonal Behavior. New York: Holt, Rinehart and Winston, 1970.

, and Arthur 5. Couch, "The Vatue Profile: A Factor Analytic Study of Value Statements." in Personality and Interpersonal

Behavior. Edited by Robert F. Bales. New York: Holt, Rinehert and Winston, 1970.

Barnhart, Clarence L., ed. Anerican Colleze Encyclopedic Dictionary. Chicago: Spencer Press, 1050.

Bush, Janice D. and John R. Bittner. "The Effect of the Video-Tape Recorder on Levels of Anxiety, Exhibitionism, and Reticence." Urpublished paper presented at the Speech-Communication Association National Convention: New Orleans, La., 1970.

Clevenger, Theodore Ir. "A Synthesis of Experimental Research in Stagefright." Quarterly journal of Speech, XLV (April, 1959), $134-145$.

Flanders, Ned A. "The Problens of Cbserver Training and Reliability." in Interaction Analysis: Theory, Research and Application. Edited by Edriund J. Ami don and John B. Hough. Reading, Mäss. : Addison Wesley, 1967.

Hansen, John H. and Robert A. Anderson. Trainer's Manual: Interaction Analysis. Portland, Oregon: Northwest Regional Educational Laboratory, 1969.

Hopf, Theodore S. Unpublished Manuscript. Summer, 1966.

- "Reticence and the Oral Interpretation Teacher." The Speech Teacher, XIX (November, 1970), 268-271. 
Ickes, William K. "A Classical Conditioning Model for Reticence." Western Speech, XXXV (Winter, 1971), 48-55.

Lustig, Myron W. and Glenn L. Ingram. "A Search of Literature for Measuring Instruments in the Area of Ora1 Communication Skil1s." Unpublished manuscript prepared for the Northwest Pegional Educational Laboratory: Portland, Oregon, March, 1971.

MacDonald, Eugene T. "A Study of Some Factors Related to Corversational Ability." Speech Monographs, XII (1945).

McNemar, Quinn, Psychological Statistics, New York: John Wiley and Sons, 1955.

Muir, Frances Laura. Case Studies of Selected Examples of Reticence and Fluency. Unpublished Master's Thesis, Washington State University: Puliman, Washington, 1964.

Phillips, Gerald M. "The Problem of Reticence." The Pennsylvania Speech Annual, XXII (September, 1965), 22-38.

- "Reticence: Pathology of the Nomnal Speakex." 'Speech Monographs, XXXV (1968), 39-49.

, and David Butt. "Reticenco Revisited." The Pennsylvania Speech Annual, XXIII (Sopterber, 1966), 40-57.

, and Eugene E. Erickson. "R' Scale." Washington State University, 1964.

Scott, Wiljiam A. "Reliability of Content Analysis: The Case of Nominal Coding." Public Opinion Quarterly. XIX (Fa11, 1955), $321-325$.

Siege1, Sidney. Nonparametric Statistics for the Behavioral Sciences. New York: McGraw Hill, Inc., 1956.

Simon, Anita and E. Gil. Boyer, eds. Mirrors For Behavior: Ain Anthology of Observation Instruments. 15 volumes. Piila., Pa.: Research for Better Schools, Inc., 1970.

Steward, Larry A. Attitudes Toward Comnunication: The Content Analysis of Interviews with Eight Reticent and Eight Non-Reticent College Students. Unpublished Ph.D. Dissertation, The Pennsy Ivania State University: University Park, Pa., 1968.

Travis, Lee Edward, ed. Handbook of Speech Pathology. New York: Appleton-Century-Crofts, Inc., 1957.

Van Riper, Charles, Speech Correction: Principles and Methods. Englewood Cliffs, N.J.: Prentice Hall, Inc., 196.5. 
APPENDICES 


\section{APPENDIX A}

\section{DEFINITIONS OF THE IN'ERACTION CATEGORIES}

In the sections that follow, each of the twelve interaction categories is defined and discussed in detail. The discussion is based, for the most part, on the definitions of the categories described by Robert F. Bales in his work Interaction Process Analysis. His definitions were modified in accordance with the purpose of this study and the means available for its conduct.

Interaction Category 1, Shows Solidarity

The interaction category Shows Solidarity is used to classify all overt acts which seem to the observer to indicate a showing of solidarity with another, a raisjng of another's status, a giving of help, or a reward. It includes any indication of mannerly consideration for the other, any indication of good will, any gesture that indicates that the person is friendly, congenial, scciable, affiliative, cordial, or informal. Any indication that the person identifies with the other, any act of forming an agreement or pact, and any act of becoming partisan on behalf of the other, is included. Also included are statusraising acts such as praising, rewarding, complimenting, showing approval or appreciation, giving support, reassurance, comfort, and consolation. Thus category 1 includes any behavior in which the person urges unity or harmony, agreement, cooperation, generosity, or expresses 
similar va ues of soiidarity. The range of acts is very great, from comparatively minor degrees of raising the other's status to very extreme recognitions of the other's superior status.

Interaction Category 2, Shows Tension Release

The interaction category Shows Tension Release is used to classify all joking, laughing, and spontaneous indications of relief which heip to create positive affect within the group. Scored here are expressions of feeling better after a period of tension, as well as any manifestation of cheerfulness, satisfaction, enjoyment, pleasure or happiness. This category includes both the element of joking, such as humorous or funny remarks, and also the positive responses to joking, such as smiling, grinning, giggling, or laughing. Abortive attempts at tension release may be scored in one of the regative social-emotional categories (Categories 10, 11, 12), depending upon the contextual. circumstances.

Interaction Category 3, Agrees

The interaction category Agrees is used to classify all instances in which a person shows passive acceptance, understands, concurs, or complies with the wishes of another. This category includes agreement, approval, or endorsement of an expression of value feeling or sentiment, as well as any indication to the observer that the actor is modest, humble, respectful, unassertive, or retiring. In response to antagonisin, Category 3 includes surrendering, giving in, standing aside, or otherwise renouncing a goal or object in favor of the other who demands it. Furthermore, nonverbal signs of approval such as nod- 
ding the head, saying "M-hmm," or other specific signs of payjing attention, are also included.

Interaction Category 4, Gives Suggestion

The interaction category Gives Suggestion includes all acts which suggest concrete ways of attaining a desired goal by attacking or modifying the outer situation, by adapting activity to it, by proposing a solution, indicating or suggesting where to start, what to do, or how to cope with a problem, in terms of action in the near future. This includes the exercise of routine or established and accepted control, or control which is exercised in such a way that it is clear that the right of request rests ultimately on the free consent of the other, and the other retains the right to protest or modify the request so that his own automony is not severely threatened. The assigninent of tasks, the appointment of persons to play a certain function in the group discussion, the delegation of authority, and other similar directional statements which maintain the autonony for the other person is included in this category.

Interaction Category 5, Gives Opinion

The interaction category Gives Opinion includes all opinion, evaluative, and analytical statements inace by the nembers of the group, as well as expressions of feelings and wishes. It includes all indications of thought-in-process leading to an understanding or dawning insight, such as introspection, reasoning, calculating, thinking or concentrating. A.lso scored in the present category are any expressions of desire, want, liking, wishing, and ary expression of sentiment, moral obligation, ambition, determination, or courage. Included here are any 
attempts to objectively understand or interpret his own or another's motivation, or the "why" of the behavior. (Statenents which are considered to be largely self-defensive rationalizations are classified under Category 12. Statements considered to be negatively toned evaluations of self or conduct are classified under Category 11). Category 5 is the workhorse of all the interaction categories. It is the category most frequertly used in many observation situations, and it includes many of those acts by which groups accompiis? their task - the problem solving, decision making, and legislative and adninistrarive work. Activity in the present category is distinguished from activity in Category 6 in that it involves inference ow interpretation rather than a simple report, reflection, or rephrasing.

Interaction Category 6, Gives oriencation

The interaction category Gives Orientation is used to classify all. acts of orientation, information, repetition, clarification, or confirmation. It includes ali efforts to repair or prevent breaks in the flow of conmunication by repeating-clarifying a misconception about something said, explaining, summarizing, or restating, not with the purpose of corvincing the other, but simply with the purpose of making the communication and understanding more adequate. Scored here are any indications of understanding the other or something the other has said by restating, paraphrasing, and clarifying the feeling involveed without inference or tells about his own past experience, thought, feeling or action. Scored in this category are all acts which are intended to facilitate the process of the activity or communication. Any act designed to focus the attention of the other, either to another person 
or the problem at hand, is scored here.

Interaction Category 7, Asks for Orientation

The interaction category Asks for Orientation refers to questions requesting a factual, descriptive or objective type answer, an answer which is based on experience, observation, or enpirical research. It includes acts which indicate a lack of krowledge sufficient to support action, such as confusion or uncertainty about the position of the group, the course of discussion to the present point, or even the meaning of a word or phrase. Included is an attitude the observer would describe as puzzled, bewildered or baffled. Thus Category 7 is used to classify all questions of orientation, information-seeking, requests for repetition, and questions of confirmation.

Interaction Category 8, Asks for Opinion

The interaction category Asks for Cpinion includes open-ended, non-directive leads and questons aimed at the exploration of the other's feclings, values, intensions, and inclinations. It specifically includes any kind of queston which attempts to encourage a statement or reaction or the part of the other without limiting the nature of the respose except in a very general way, with the implication that the other person has the freedom to express his true interests or disinterests without pressure to agree or disagree with other answers or attitudes. This kind of behavior occurs in group interaction where there is a desire and atempt on the part of a member to sound the other's feelings on a problem.at any point where evaluation may come into play. It includes explicit or implicit evaluative requests, such 
such as questions, statements, responses, or other similar acts. The inference requested may refer to the outer situation facing the group, to the group itself, to its structure or organization, to the other person, or to the self.

Interaction Category 9, Asks for Suggestion

The interaction category Asks for Suggestion is meant to define acts which indicate a question or request, explicit or implicit, for suggestions as to how an action shall proceed. Often such acts will also indicate a feeling of confusion or uncertainty about the position of the group with regard to its goals, the course of discussion to the present point, or about what has been said or going on. Requests for suggestions are to where to start, what to do next, and what to decide, which are meant to begin a crystalijzation of a concrete plan of action, are also included. Appeals for suggestions which have an emotional undertone of dependence, or of a need for help, an inability to take responsibility for direction rather than a sharing of the right to determine direction, are classifed as Show Tension (Category 11).

Interaction. Category 10, Disagrees

The interaction category Disagrees is used to classify any indication of an attitude which the observer considers as in disagreement, uncommunicative, passively rejecting, or withholding. It includes any situation in which an enlotional response would be expected but not carried out, such as remaining jmmobile, restrained, silent, detached, isolated, indifferent, impersonal, unsocial, reserved, secluded or forbidding. All undetermined member-to-member contracts, that is 
asides, whisprering, winks, etc., while the main discussion is going on between others are classified in this category. In general, however, only the initial reaction of disagreement is marked in the present category, when the disagreement is essentially one of ideas. The arguments which follow in the form of statements about the situation, are scored in their respective categories. Example: "I don't think so, It seems to me that there were more than that. In fact, I remenber seeing at least six." In the foregoing statement only "I don't think so," would be scored in the present category. The argument which follows is broken up and scored in the task-oriented categories described above.

Interaction Category 11, Shows Tension

The interaction category Shows Tension includes all sorts of nomfocal manifestations of impatiences, such as anxiety, self-consciousness, depression, unhappiness, or any behavior which indicates to the observer that the person is unattentive, bored, or psychologically withdrawn from the problem at hand. This may evidence itself by slouching, yawning, looking away from the others in the group, or other overt indications of anxious emotionality, such as hesitation, speechlessness, blushing, stammering, or verbal disjunctivity. It includes any verbal or motor expression of fear, apprehension, worry, dread, or fright, as well as the appearance of various "nervous habits" - doodling, self-grooming, biting the nails, playing with sone object, or other similar behaviors. Where the behavior is constant, a new score is entered once each minute. Also included are any indication on the part of a person that his effort has failed, that some problems confrontins him in his earlier efforts still 
remain, and that he feels frustrated, thivarted, or in some manner deprived of accomplishing a predetermined goal.

\section{Interaction Category 12, Shows Antagonism}

The interaction category Show's Antagonism is used to categorize any attenpt to demonstrate control, any attenpts to declare active autonomy in the face of control, any ramarks which the observer regards as deflating of the other's status or defending of his own, as well as any manifestations of diffuse emotional aggression. Scored here are any attempt to regulate, govern, direct, or supervise the other in a manner which is interpreted as autocratic, in which freedon of choice for the other person is greatly lunited, with the implication that the other has no right to protest or modify the demand but is expected to follow the directive inmediately without argument. Any act in which the person preenptorily beckons, points, pushes, pulls, or otherwise directly controls or attempts to control the activity of the other is included. Also scored here are any responses to attempts at control in which the person is unwilling, disobliging, noncompliant, or in which he rejects, refuses, or purposefully ignored directions, commands, demands, or authoritative requests. Status deflating acts such as attempts to override the other in conversation, interrupting the other, teasing, scoffing or provoking the other to say something indiscrete or damaging, are also included. Any act impugning the character of the other, any acts of gossip, discredit or informing against him, are included. Generally speaking, all agressive, threatening, challenging, attacking, or vindictive behaviors are included in this category. 


\section{APPENDIX B}

\section{NASA GROUP CONSENSUS PEOBLEM}

Your group represents the crew of a space ship that was scheduled to land at a space station on the 1ighted surface of the moon. Due to a radar error during powerea descent you have landed some 200 miles away from the station. The rugged terrain on which you have landed caused much damage to your ship and equipment and, since the survival of each and ali of you depends on your reaching the space station, the most critical items available must be selected for the 200-inile trip. Below are listed the fifteen items left intact and undamaged after the landing. Your task is to order these itens in terms of their importance in helping you reach the space station.

Select a group reporter and, on the basis of the group's consensus on the importance of the items, place the number 1 in front of the inost important item and 2 in front of the second most important, and so on through number 15, the least inportant.

Box of safety matches Carton of dehydrated food

50-foot length of rope

Parachute sj.1k

portable heating unit Two .45 caliber pistols and cartridges 
Carton of dehydrated milk

Two $100 \mathrm{lb}$. tanks of oxygen

Stellar map (of the moon's constellation)

Inflatable life raft

Magnetic compass

5 gallons of water

Signal light (high intensity)

First-aid kit containing injection needles

Solar-pcwered FM transmitier-receiver 


\section{KEY TO NASA PROBIDM}

\begin{tabular}{|c|c|}
\hline 15 & Box of safety matches \\
\hline 5 & Carton of dehydrated food \\
\hline 6 & 50-foot length of rope \\
\hline 8 & Parachute silk \\
\hline 13 & Portable heating unit \\
\hline 11 & Two .45 caliber pistols and cartridges \\
\hline 12 & Carton of dehydrated milk \\
\hline 1 & Two $100 \mathrm{lb}$, tajks of oxygen \\
\hline 3 & Stellar map (of the moon's corstellation) \\
\hline 9 & Infiatable life raft \\
\hline 14 & Magnetic compass \\
\hline 2 & 5 gallons of water \\
\hline 10 & Signal light (high intensity) \\
\hline 7 & First-aid kit containing injection needles \\
\hline 4 & Solar-powered FM transmitter-receiver \\
\hline
\end{tabular}




\section{APPENDIX C \\ GRIEVANCES OF BLACK CITIZENS CONSENSUS PROBL̈EM}

During the Fall of 1967 the research staff of the National Advisory Cormission on Civil Disorders (the Kerner Commission) studied conditions in 20 cities which had experienced riots during 1967 . The 20 cities were made up of nine cities which had experienced major destruction, six New Jersey cities surrounding Newark, and five cities which experienced lesser degrees of violence.

In each city staff members interviewed persons from the officiai sector (maycrs, city officiais, policemen and police officiajs, judges, and others), the disorder area (residents, leaders of comminity groups) and the private sector (businessmen, labor leaders, and comnuity leaders) Altogether over 1200 persons were interviewed.

Using this material the investigators identified and assigned weights to the four types of grievances which appearcd to have the greatest significance to the black community in eacil city. For each city they made judgnients about the severity of a particular grievance and assigned a rank to the four most serious. These judgnents were based on the frequency with which a particular grievance was mentioned, the relative intensity with which it was discussed, references to incidents exemplifying the grievance, and estimates of severity obtained from the intervicwees themselves. 
Four points were assigned to the most serious type of grievance in each city, tiree points to the second most serious, and so on throligh all four.

When the point values were added for all cities, a list of 12 grievance types emerged, rank-ordered. The grievance type which was considered the most serious in the most cities was number 1 . The one which seemed generaily least serious was number 12 .

Following this explanatory introduction are the 12 grievance types reported by the Kerner Commission. Your group is to arrive at a single rank-ordering of the 12 grievances that each member of the group will. support as the single best prediction of the rank-order reported by the staff of the Kerner Commission.

put a 1 beside the type of grievance you believe the stafe judged that black citizens felt to be the most serious to them across all 20 cities. Put a 2 beside the second most serious and pervasive, and so on down to a 12 beside the least widespread the least serious.

This is an exercise in the use of consensus to make decisions. Consensus is not the same as unanimity. A vote of 12 to 0 is unaninous, but it may not be based on consensus. The essential feature of a consensus is not that a decision is agreed to be all members, but that all members understand the reasoning leadirg to the decision and are willing to support the decision. Each member may not completely agree with the decision, but ali feel they have had a fair chance to influence the decision, that others have understood their information and opinions and taken them into account. The final decision, thus, is one which they understand and are willing to give enlightened support. In striving for 
consensus, then, the emphasis is upon reasoning about the problem and creating solutions together rather than on coercing and persuading others to adopt a particular solution.

In trying to reach consensus about the way the Kerner Commission staff rank-ordered the 12 grievances, the following guides may help.

1. Try to view disagreements and differences of opinion as showing the rieed for fuilex commication and fuller mutual understanding rather than as evidence of stubbornness.

2. Approach the task by sharing information, reasoning together and exploring possibilitios together rather than by attempting to change other persons' minds to coiricide with your position.

3. Avoid trading or averaging as a way of making decisions.

4. Avoid changing your mind only in order to give the appearance of unanimity. Support only solutions which you understand and believe to have a reasonable basis.

5. When the groip is deadlocked and the issue seems to have been thoroughly examined; try to create a method of resolving the deadlock that all can support as the best course of action at that time. That is, try to develop a consensus on the method of deciding the issue. 
A. Inadequate Education: de facto segregation, poor quality of instruction and facilities, inadequate curriculum, etc.

B. Disrespectful White Attitudes: racisin and lack of respect for dignity of Negroes.

C. Inadequate Municipai Services: inadequate sanitation and garbage removal, inadequate health care facilities, etc.

D. Discrininatory Police Eractices: physical or verbal abuse, no grievance channels, discrimination in hiring ard promoting Negroes, etc.

E. Inadequate Housing: poor housing cods enforcement, discrimination in sales and rentals, overcrowding.

F. Inadequate Welfare Programs: unfair qualitication regulations, attitude of welfare workers toward recipients.

G. Poor Recreational Facilities: inadequate parks, playgrounds, etc. Lack of organized prograns.

H. Unemployment and Underempjoyment: discrinination in hixing and placement by organizations or by unions. General lack of full time jobs, etc.

I. Administration of Justice: discriminatory treatment in the courts, presumption of guilt, etc. 
Your Ranking

J. Inadequate Federal Programs: insufficient participation by the poor, lack of contiruity, inadequate funding.

K. Discriminatory Consumer \& Credit Practices: Negroes sold inferior quality goods at higher prices, excessive interest rates, fraudulent commercial practices.

I. Unresporisive Political Structure: inadequate reprcsentacion of Negroes, lack of response to complaints, obscurity of official grievance channels. 
GRJEVANCES OF BLACK CITIZENS

Key ...- Rank-Order reported by Kerner Commission Staff

Grievance Type $\quad$ Rank $\begin{aligned} & \text { No. of } \\ & \text { Cities }^{a}\end{aligned}$

A. Inadequate Education ............. $4 \quad 9 \quad 21 \ldots$

B. Disrespectfui White Attitucies $\ldots \ldots \ldots, 7 \quad 4.5$

C. Inadequate Municipal Services ....... $10 \quad 10 \quad 12$

D. Discriminatory Police Practices ..... 1 . $14 \quad 45.5$

E. Inadequate Housing ............. 3 314

F. Inadequate Welfare Prograns ....... $12 \quad 0$.

G. Poor Recreational Facilities ....... 5 5 41

H. Unemployment and Underempioyment .... $2 \quad 2 \quad 17 \quad 42$

I. Administration of Justice ......... 8 . 8 3 4.5

J. Inadequate Federal Programs ......... 9912.5

K. Discriminatory Consumer and Credit Practices ..................... 11

L. Unresponsive Political. Struct:xre $\ldots . .665014$

a. How many of the 20 cjties in which this grievance type was one of the four most serious.

b. The total of points for each category is the product of the number of cities times 4 points for most serious, 3 points for second most serious, 2 points for third most serious, and 1 point for 4 th most serious grievance. 
The previous problem is based uxom: Peyort of the National Advisory Comnission on Civil Disorders, 1568, Bantam 5ooks, p. 149. 